\title{
Change in hydraulic properties and leaf traits in a tall rainforest tree species subjected to long-term throughfall exclusion in the perhumid tropics
}

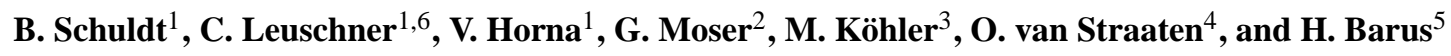 \\ ${ }^{1}$ Plant Ecology, Albrecht von Haller Institute of Plant Sciences, University of Göttingen, Grisebachstrasse 1, \\ 37077 Göttingen, Germany \\ ${ }^{2}$ Plant Ecology, University of Gießen, Heinrich-Buff-Ring 26, 35392 Gießen, Germany \\ ${ }^{3}$ Tropical Silviculture and Forest Ecology, Burckhardt Institute, University of Göttingen, Büsgenweg 1, \\ 37077 Göttingen, Germany \\ ${ }^{4}$ Soil Science of Tropical and Subtropical Ecosystems, Büsgen-Institute, Georg-August-University of Göttingen, \\ Büsgenweg 2, 37075 Göttingen, Germany \\ ${ }^{5}$ Agrotechnology, Faculty of Agricultural Sciences, Tadulako University, 94118 Palu, Sulawesi Tengah, Indonesia
}

Received: 13 October 2010 - Published in Biogeosciences Discuss.: 24 November 2010

Revised: 3 August 2011 - Accepted: 5 August 2011 - Published: 12 August 2011

\begin{abstract}
A large-scale replicated throughfall exclusion experiment was conducted in a pre-montane perhumid rainforest in Sulawesi (Indonesia) exposing the trees for two years to pronounced soil desiccation. The lack of regularly occurring dry periods and shallow rooting patterns distinguish this experiment from similar experiments conducted in the Amazonian rainforest. We tested the hypotheses that a tree's sun canopy is more affected by soil drought than its shade crown, making tall trees particularly vulnerable even under a perhumid climate, and that extended drought periods stimulate an acclimation in the hydraulic system of the sun canopy. In the abundant and tall tree species Castanopsis acuminatissima (Fagaceae), we compared 31 morphological, anatomical, hydraulic and chemical variables of leaves, branches and the stem together with stem diameter growth between drought and control plots.
\end{abstract}

There was no evidence of canopy dieback. However, the drought treatment led to a $30 \%$ reduction in sapwoodspecific hydraulic conductivity of sun canopy branches, possibly caused by the formation of smaller vessels and/or vessel filling by tyloses. Drought caused an increase in leaf size, but a decrease in leaf number, and a reduction in foliar calcium content. The $\delta^{13} \mathrm{C}$ and $\delta^{18} \mathrm{O}$ signatures of sun canopy leaves gave no indication of a permanent down-regulation of

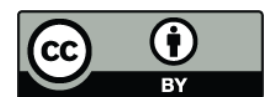

Correspondence to: C. Leuschner (cleusch@gwdg.de) stomatal conductance during the drought, indicating that presenescent leaf shedding may have improved the water status of the remaining leaves. Annual stem diameter growth decreased during the drought, while the density of wood in the recently produced xylem increased in both the stem and sun canopy branches (marginally significant). The sun canopy showed a more pronounced drought response than the shade crown indicating that tall trees with a large sun canopy are more vulnerable to drought stress.

We conclude that the extended drought prompted a number of medium- to long-term responses in the leaves, branches and the trunk, which may have reduced drought susceptibility. However, unlike a natural drought, our drought simulation experiment was carried out under conditions of high humidity, which may have dampened drought induced damages.

\section{Introduction}

Tropical forests are likely to encounter more frequent and severe droughts as a result of climate change (Allen et al., 2010; Meir and Woodward, 2010). Regional studies have developed rainfall and drought scenarios for South-East Asia (Hulme and Viner, 1998; Timmermann et al., 1999; Williams et al., 2007; Bates et al., 2008; Newbery and Lingenfelder, 2009; Sheffield and Wood, 2008) and South America (Cox et al., 2008; Phillips et al., 2009, 2010). Rainfall manipulation

Published by Copernicus Publications on behalf of the European Geosciences Union. 
experiments have been found to be powerful tools for detecting gradual ecosystem responses and threshold values of ecosystem functions to simulated droughts (Hanson and O'Hara, 2003). In tropical forests, experiments with reduced throughfall have been conducted only in Amazonia under climates with distinct dry periods (Nepstad et al., 2002, 2007; Fisher et al., 2007; da Costa et al., 2010), where many species possess drought adaptations, e.g. deep-reaching roots. However, we expect that the results of these Amazonian experiments cannot simply be extrapolated to tropical forests with a perhumid climate, where most species lack drought resistance/avoidance strategies (Aldrian and Susanto, 2003; Aldrian et al., 2004; Erasmi et al., 2009). Experiments on the drought response of trees from perhumid climates with continuously high soil moisture and air humidity do not yet exist.

Both observational studies during natural drought events and throughfall exclusion experiments indicate that tall canopy trees suffer higher mortality rates under extended drought than smaller trees (Slik et al., 2004; Van Nieuwstadt and Sheil, 2005; Nepstad et al., 2007; da Costa et al., 2010; Phillips et al., 2009, 2010; Floyd et al., 2009). However, the underlying physiological basis of this response is not well understood.

High hydraulic conductance appears to be an essential prerequisite for high productivity in trees (Tyree, 2003). Further, tall trees are generally more productive than shorter ones (Sillett et al., 2010), and should possess more conductive sapwood compared to smaller trees. According to the Hagen-Poiseuille equation, high hydraulic conductivity can be achieved through increased vessel size and/or number. Because conduit conductivity increases to the fourth power of diameter, wide vessels are much more conductive than narrow ones and may be associated with high productivity, but at the same time, wide conduits are likely more prone to drought-induced cavitation than narrow ones (e.g. Zhu and Cao, 2009; Awad et al., 2010; Blackman et al., 2010; Cai and Tyree, 2010; Hacke et al., 2010). Water movement through the vascular system from the soil to the distal leaves encounters resistance to flow as path-length and the effects of gravity increase. Accordingly, insufficient water supply to the leaves has been hypothesized as a limiting factor to height growth in tall trees (Ryan and Yoder, 1997; Koch et al., 2004). Hydraulic dysfunction in tall trees may occur even in moist climates because cavitation events can occur more frequently at greater heights (McDowell et al., 2002). On the other hand, adjustments in tree hydraulic architecture can compensate for the greater hydraulic resistance encountered by tall trees (Ambrose et al., 2010). Nevertheless, hydrostatic effects associated with tree height may cause changes in leaf morphology (Cavaleri et al., 2010; Oldham et al., 2010). During leaf development, leaf elongation is dependent on sufficient turgor pressure, which allows cellular expansion (Cosgrove, 1993). Thus, water deficits may lead to decreased cell expansion and decreased leaf size.
Trees respond to soil drought by acclimation and adaptation processes at multiple spatial and temporal scales. Shortterm responses include stomatal closure and access to stored water, thereby potentially avoiding hydraulic failure (Holbrook, 1995; Phillips et al., 2003; Borchert and Pockman, 2005). More severe drought events may lead to the dieback of fine roots, the shedding of leaves and reduced stem growth (Tyree et al., 1993; Ichie et al., 2004) if organ- and speciesspecific water status thresholds are crossed. Stress-induced leaf shedding increases the Huber value, the ratio of conducting sapwood area to leaf area, which may consequently improve the water status of the remaining leaves.

Long-term acclimation to drought may include structural and physiological adjustments in the tree's hydraulic architecture and alterations in leaf morphology and roots. These responses may facilitate tree survival under the anticipated effects of climate change. Drought-exposed trees could secure their water supply to the crown by increasing the embolism resistance of their conduits (Poyatos et al., 2007), grow deeper roots, reduce their leaf area, become shorter, or produce smaller leaves with higher cell wall elasticity. Additionally, drought-affected trees may have to cope with reduced foliar nutrient concentrations, which may result from slower rates of nutrient diffusion and uptake in dry soil (Rennenberg et al., 2009; Kreuzwieser and Gessler, 2010). If, and to what extent, tropical trees are able to accomplish these morphological and physiological adjustments is not well understood. Uncertainty exists in particular with respect to the adaptability of mature trees found in tropical forest regions that do not experience seasonal dry periods.

We established a replicated throughfall exclusion experiment (Sulawesi Throughfall Exclusion Experiment, STEE) in a pre-montane perhumid rainforest in Central Sulawesi, Indonesia, and measured the changes in sapwood-specific conductivity, vessel anatomy, leaf morphology, and leaf nutrient concentrations that occurred in a single species ( $\mathrm{Cas}$ tanopsis acuminatissima) in response to a 24-month experimental drought. The study region is characterized by high rainfall and humidity throughout the year, with humidity rarely falling below $80 \%$. This environmental setting is in marked contrast to the climatic conditions at the two established throughfall exclusion experiments conducted in Amazonia (Nepstad et al., 2002, 2007; Fisher et al., 2007; da Costa et al., 2010). In this study, we focused on the drought response of the prominent forest tree species $C$. acuminatissima (Blume) Rheder, a tall tree of the Fagaceae family that dominates the stands in terms of biomass and size (Culmsee et al., 2010). Previous studies suggest that soil drought is a threat to tall $C$. acuminatissima trees because of their tall stature, wide vessels (Zach et al., 2010; B. Schuldt, unpublished data), and consequently high water consumption (Horna et al., 2011). Furthermore, excavations showed that this stand has a shallow root system (Hertel et al., 2009), apparently lacking the deep root characteristics of Amazonian forest species (Markewitz et al., 2010). Shallow roots may 
further predispose $C$. acuminatissima to drought-induced cavitation.

The study's objectives were to compare morphological, anatomical, hydraulic and chemical traits at the leaf, branch and stem levels in mature $C$. acuminatissima trees between droughted (24 months) and control plots in order to identify traits sensitive to water shortage. Because leaf exposure and canopy position exert a large influence on leaf morphology and physiology in tall trees, we investigated leaves and branches of both the sun and shade canopy and compared their response to the two-year drought. We expected the upper crown to be more susceptible to drought stress than the lower crown because the cavitation risk typically increases with flow path length and with exposure to elevated vapor pressure deficits, which increases with canopy height.

We hypothesized that (i) the two-year drought period would increase the leaf-specific hydraulic conductivity and the Huber value of branches due to pre-senescent leaf shedding and anatomical adjustments in the newly formed xylem, (ii) leaves produced during the drought would be smaller with reduced concentrations of $\mathrm{N}, \mathrm{P}$ and other elements due to drought-induced nutrient shortage, and (iii) morphological and anatomical differences between drought-exposed and control trees would be most pronounced in sun-exposed leaves and branches at the end of the flow path, where hydraulic resistance is highest.

\section{Material and methods}

\subsection{Site description}

The Sulawesi Throughfall Exclusion Experiment (STEE) was established in 2006 in a premontane rainforest in the Pono Valley on the western boundary of Lore Lindu National Park in Central Sulawesi, Indonesia (01 ${ }^{\circ} 29.6^{\prime} \mathrm{S}, 120^{\circ} 03.4^{\prime} \mathrm{E}$, elevation $1050 \mathrm{~m}$ ). The climate of the study area is perhumid with a mean annual precipitation of $2901 \mathrm{~mm}$, a mean annual temperature of $20.6^{\circ} \mathrm{C}$ and a mean relative air humidity of $88.7 \%$ (based on own measurements in the forest in 2008). The heavily weathered soils of this old-growth forest developed on metamorphic rocks. The clayey-loamy soil texture with dominant kaolinite and hematite has been classified as Nitisol (World Reference Base for Soil Resources). The forest has a canopy height of about $45 \mathrm{~m}$ with a few trees reaching $55 \mathrm{~m}$, a high tree species diversity with about 130 species ha ${ }^{-1}$, an average stem density of $456 \mathrm{ha}^{-1}$ and a basal area $\left(A_{\mathrm{B}}\right)$ of $43.4 \mathrm{~m}^{2} \mathrm{ha}^{-1}(>10 \mathrm{~cm}$ diameter at breast height (DBH), Culmsee and Pitopang, 2009; Culmsee et al., 2010).

\subsection{Experimental design}

The STEE consisted of six floristically and structurally similar plots of $0.16 \mathrm{ha}(40 \times 40 \mathrm{~m})$ that were spread in a stratified random design over an area of approximately five hectares.
While three plots served as control (stand basal area: $\left.46.46 \mathrm{~m}^{2} \mathrm{ha}^{-1}\right)$, the remaining three plots $\left(40.26 \mathrm{~m}^{2} \mathrm{ha}^{-1}\right)$ were covered by sub-canopy roofs to displace a large fraction of the rainfall. The roofs were constructed with a large number of removable transparent plastic-lined bambooframes placed on a wooden gutter construction to collect the throughfall water. The soil desiccation period started in May 2007. At the beginning, approximately $50 \%$ of the plot area was covered by the bamboo frames. In early 2008 , the roof closure was further increased to approximately $80 \%$ by building custom-sized panels to close gaps around the tree stems and odd-sized openings. To avoid lateral soil water movement or infiltration of surface runoff into the plots and to disable trees to take up water from the surroundings of the study plots, all plots were trenched along the perimeter to $0.4 \mathrm{~m}$ soil depth and lined with plastic foil. Since $74 \%$ of the fine root and $91 \%$ of the coarse root biomass are located in the upper $20 \mathrm{~cm}$ of the soil profile in this forest (Hertel et al., 2009), we assumed this trenching depth to be sufficient to effectively prevent root water uptake from beyond the plot edges. The litter, which had accumulated on top of the roof construction or in the runoff channels, was transferred back to the soil surface.

\subsection{Microclimatic and hydrologic measurements}

Above-canopy global radiation $(R)$ was measured with a pyranometer (CS 300, Campbell Scientific, UK), air temperature $(T)$ and relative humidity $(\mathrm{RH})$ were recorded with a combined temperature and humidity probe (CS 215, Campbell Scientific, UK). Rainfall was measured to the nearest $0.1 \mathrm{~mm}$ with a tipping bucket rain gauge (ARG100, Campbell Scientific, UK). All sensors were mounted on a $16 \mathrm{~m}$ tall tower located in a natural forest gap approximately $50 \mathrm{~m}$ away from the first study plot. Data were collected every $30 \mathrm{~s}$, averaged and logged at 30-min intervals using a Campbell CR800 data logger (Campbell Scientific, UK). Atmospheric vapor pressure deficit $(D)$ was calculated from $T$ and RH according to Goff and Gratch (1946).

For monitoring vertical changes in stand microclimate, especially the increase of $D$ with forest height, we installed three $40 \mathrm{~m}$-long ropes from the canopy top to the forest floor equipped with temperature and air humidity sensors $\left(\mathrm{HOBO}^{\circledR}\right.$ H8 Pro Series, Onset Computer Corporation, Bourne, USA) that registered $T$ and $\mathrm{RH}$ at five heights above ground $(5,10,15,20,25$ and $30 \mathrm{~m})$ at 30 min-intervals for 12 days in June 2009 (days of year 159-170). This period represented a low-rainfall period in the study area with $15.5 \mathrm{~mm}$ of rainfall recorded on five nights (data not shown).

Volumetric soil water content $(\theta)$ was continuously measured in one main and two additional soil pits per plot. In the main soil pit, time domain reflectometry (TDR) probes (CS616, Campbell Scientific, UK) were installed at 10, 20, $40,75,150$ and $250 \mathrm{~cm}$ soil depth. The two additional soil pits were equipped with TDR probes in 10,40 , and $75 \mathrm{~cm}$ soil 
Table 1. Means of air temperature $(T)$, relative humidity $(\mathrm{RH})$ and vapor pressure deficit $(D)$ at mid-canopy height (16 m) in the two experimental years for full days and the daytime periods only in the Pono forest.

\begin{tabular}{llll|lll}
\hline & \multicolumn{3}{c}{ Full day (24h) } & \multicolumn{3}{c}{ Daylight hours (12h) } \\
\cline { 2 - 7 } & $T\left({ }^{\circ} \mathrm{C}\right)$ & $\mathrm{RH}(\%)$ & $D(\mathrm{kPa})$ & $T\left({ }^{\circ} \mathrm{C}\right)$ & $\mathrm{RH}(\%)$ & $D(\mathrm{kPa})$ \\
\hline 1st year & $20.8 \pm 0.7$ & $88.5 \pm 5.1$ & $0.34 \pm 0.16$ & $22.4 \pm 1.0$ & $82.4 \pm 6.9$ & $0.54 \pm 0.24$ \\
2nd year & $20.6 \pm 0.8$ & $88.9 \pm 3.9$ & $0.32 \pm 0.13$ & $22.3 \pm 1.1$ & $82.9 \pm 6.0$ & $0.53 \pm 0.22$ \\
\hline
\end{tabular}

depth. The probes were inserted horizontally in the undisturbed soil at the end of a $30 \mathrm{~cm}$ long hole dug into the soil pit wall. In total, 36 TDR probes were operated per treatment and the data was logged hourly (CR1000, Campbell Scientific, UK). The TDR probes were calibrated for all soil depths following the procedure described by Veldkamp and O'Brian (2000).

The hydrological and physiological measurements began on 27 March 2007 in the drought plots and on 31 May 2007 in the control plots. A lightning strike in March 2007 was responsible for the delayed onset of the measurements in the control as it damaged both dataloggers and TDR probes.

\subsection{Relative extractable water and soil water potential}

The soil moisture measurements were used to calculate the relative extractable water (REW) in the soil profile using the following equation (Breda et al., 2006; Granier et al., 2007):

$\mathrm{REW}=\frac{\left(\theta_{t}-\theta_{\min }\right)}{\left(\theta_{\max }-\theta_{\min }\right)}$

where $\theta_{t}$ is the fractional volumetric soil water content on the respective day, $\theta_{\min }$ the soil water content at that all plant-available water is extracted (corresponding to the water content at wilting point in a given soil depth), and $\theta_{\max }$ the maximum water content measured during the study in a given soil depth. The volumetric soil water content at the permanent wilting point was calculated from laboratoryderived soil water retention curves (Van Genuchten, 1980) using pressure plates. REW varies between 1 (field capacity or maximal measured soil water content) and 0 (permanent wilting point). According to Granier et al. (2007), temperate trees typically experience drought stress when REW drops below a threshold of 0.4. The soil water retention curves were used to calculate soil matric potentials from the soil moisture measurements for all soil depths in the two treatments.

Due to a lightning strike, which damaged the TDR installation, no pre-treatment soil moisture comparison between control and drought plots was possible. A good matching between drought and control plots in terms of soil moisture was evidenced, however, by the good agreement in the $\theta$ values ( $0.1 \mathrm{~m}$ depth) between the control plots during the experiment and those of the drought plots before root closure.

\subsection{Tree selection and plant material}

In June 2009, after 24 months of experimental drought, 14 tree individuals (control $n=7$, drought $n=7$ ) of the most abundant and tallest upper-canopy tree species of the studied forest, $C$. acuminatissima, were chosen to collect branch and leaf material from the upper sun-lit canopy and from the lowermost deeply shaded part of the crown using tree climbing equipment. These samples were used to obtain data on branch wood specific gravity (wood density), branch hydraulic properties, branch wood anatomy, leaf morphology and foliar nutrient status. In addition, wood cores were taken from the trunk of every tree at $1.5 \mathrm{~m}$ height to determine the wood density and wood anatomy of the trunk.

\subsection{Wood density and saturated water content determination}

Wood density $(\rho)$ was determined for trunk wood cores with a diameter of $5 \mathrm{~mm}$ and a mean core length of $69.5 \pm 1.9 \mathrm{~mm}$ using an increment corer (Haglöf, Långsele, Sweden) and for branch wood samples from the upper and lower crown with a mean segment diameter of $33.1 \pm 0.7 \mathrm{~mm}$ and a mean segment length of $126.4 \pm 1.46 \mathrm{~mm}$. In total, 109 branch segments were harvested in the 14 C. acuminatissima trees. The fresh volume of the wood cores was calculated from the diameter of the increment corer and the length of the core sample after removing bark and phloem; the fresh volume of the branch samples was determined gravimetrically by water displacement according to Archimedes' principle. After volume determination, all samples were oven-dried at $105^{\circ} \mathrm{C}$ for at least four days. The dry wood cores were weighed at a precision of $0.1 \mathrm{mg}$, the branch segments at a precision of $10 \mathrm{mg}$. The dry mass of each sample was then divided by its fresh volume to obtain $\rho$. The trunk wood cores were further used to determine the saturated water content of the wood (SWC). The cores were submerged in deionized water and allowed to equilibrate overnight. Afterwards, the cores were lightly blotted with tissue paper and weighed at a precision of $0.1 \mathrm{mg}$. 
Table 2. Biometric characteristics of 14 individual C. acuminatissima trees and morphological, anatomical and hydraulic characteristics of the trunks at $1.5 \mathrm{~m}$ height. Diameter at breast height $(\mathrm{DBH}, \mathrm{cm})$, total tree height $\left(H_{\text {high }}, \mathrm{m}\right)$, canopy base height $\left(H_{\text {low }}, \mathrm{m}\right)$, stem wood density $\left(\rho_{\text {stem }}, \mathrm{kg} \mathrm{m}^{-3}\right)$, saturated water content of stem wood (SWC, \%), vessel lumen area $\left(A_{\text {Lumen }}, \%\right)$, vessel density $(\mathrm{VD}$, $\left.\mathrm{n} \mathrm{mm}^{-2}\right)$, mean vessel diameter $(d, \mu \mathrm{m}$, mean $\pm \mathrm{SE})$, hydraulic mean diameter $\left(d_{\mathrm{h}}, \mu \mathrm{m}\right)$ and theoretical sapwood-specific conductivity $\left(k_{\mathrm{S}}^{\text {theo }}, \mathrm{kg} \mathrm{m}^{-1} \mathrm{MPa}^{-1} \mathrm{~s}^{-1}\right)$ in the drought and control treatments (control: C1-C7, drought: D1-D7). For level of significance $(p)$ see Table A6 in the Supplement.

\begin{tabular}{lccccrrrrrr}
\hline Tree & DBH & $H_{\text {high }}$ & $H_{\text {low }}$ & $\rho_{\text {stem }}$ & SWC & $A_{\text {Lumen }}$ & VD & $d$ & $d_{\mathrm{h}}$ & $k_{\mathrm{S}}^{\text {theo }}$ \\
\hline C1 & 68.6 & 31.6 & 15.0 & 491.4 & 117.8 & 21.4 & 4.2 & $250.3 \pm 5.8$ & 291.4 \\
C2 & 35.6 & 49.9 & 17.0 & 541.8 & 105.5 & 19.8 & 3.1 & $279.7 \pm 6.1$ & 320.8 & 615.4 \\
C3 & 56.2 & 35.6 & 22.0 & 511.0 & 112.0 & 9.9 & 2.0 & $248.0 \pm 6.1$ & 284.2 \\
C4 & 48.0 & 39.7 & 15.0 & 480.1 & 130.6 & 11.2 & 2.8 & $215.9 \pm 6.8$ & 267.9 & 240.2 \\
C5 & 44.7 & 29.6 & 15.0 & 545.3 & 110.9 & & & & & \\
C6 & 71.4 & 38.1 & 20.0 & 535.8 & 105.2 & 12.9 & 2.8 & $238.2 \pm 5.2$ & 275.6 & 291.2 \\
C7 & 67.8 & 43.9 & 25.0 & 490.8 & 113.9 & 18.0 & 3.4 & $249.5 \pm 6.3$ & 309.8 & 505.5 \\
\hline Control & $56.0 \pm 5.2$ & $38.2 \pm 2.7$ & $18.4 \pm 1.5$ & $513.0 \pm 10.3$ & $113.7 \pm 3.3$ & $15.6 \pm 2.0$ & $3.1 \pm 0.3$ & $247.4 \pm 2.6$ & $291.6 \pm 8.3$ & $408.9 \pm 68.8$ \\
\hline D1 & 63.8 & 40.5 & 14.0 & 555.0 & 95.9 & 13.6 & 3.2 & $226.9 \pm 5.8$ & 277.1 & 311.4 \\
D2 & 49.8 & 41.0 & 20.0 & 545.4 & 100.4 & 13.2 & 2.9 & $234.7 \pm 5.3$ & 272.8 & 292.3 \\
D3 & 56.9 & 48.8 & 20.0 & 525.4 & 99.9 & 18.6 & 3.8 & $248.1 \pm 4.0$ & 276.6 & 435.3 \\
D4 & 81.0 & 34.8 & 25.0 & 496.8 & 124.5 & 12.8 & 2.8 & $232.0 \pm 6.5$ & 291.3 & 317.0 \\
D5 & 52.7 & 37.0 & 20.0 & 533.0 & 105.8 & 14.1 & 3.3 & $231.5 \pm 4.2$ & 257.4 & 283.1 \\
D6 & 59.4 & 39.6 & 15.0 & 540.5 & 102.5 & 13.9 & 2.9 & $237.7 \pm 6.1$ & 289.6 & 346.5 \\
D7 & 44.7 & 40.5 & 15.0 & 575.6 & 90.5 & 20.1 & 3.4 & $267.4 \pm 6.1$ & 315.2 & 594.8 \\
\hline Drought & $58.3 \pm 4.5$ & $40.3 \pm 1.7$ & $18.4 \pm 1.5$ & $538.8 \pm 9.3$ & $102.8 \pm 4.1$ & $15.2 \pm 1.1$ & $3.2 \pm 0.1$ & $240.1 \pm 2.1$ & $282.9 \pm 6.9$ & $368.6 \pm 42.3$ \\
\hline
\end{tabular}

\subsection{Stem diameter increment}

Stem diameter increment was measured with dendrometer bands (UMS, Munich, Germany) that were installed in December 2006 on 14 individual trees of $C$. acuminatissima (control $n=5$, DBH $57.4 \pm 9.6 \mathrm{~cm}$; drought $n=9$, DBH $54.5 \pm 6.8 \mathrm{~cm})$. Diameter increase was registered monthly until the end of the desiccation period in May 2009. Annual stem diameter increment was calculated separately for the first and the second year of the desiccation experiment. There was no correlation between absolute diameter increment and $\mathrm{DBH}$, and therefore no correction of increment data for plant size was applied.

\subsection{Experimental determination of axial hydraulic conductivity}

The technique introduced by Sperry et al. (1988) was applied to measure axial hydraulic conductivity in branch segments. In total, 116 measurements were analyzed (control $n=56$, drought $n=60)$. For each individual tree, eight branch segments of $139.7 \pm 3.2 \mathrm{~mm}$ length and $10.6 \pm 0.1 \mathrm{~mm}$ in diameter were harvested, four from the upper canopy and four from the lower crown. These segments were immediately transferred to polyethylene tubes filled with water containing a sodium-silver-chloride complex $\left(16 \mu \mathrm{g} \mathrm{l}^{-1} \mathrm{Ag}\right.$, $8 \mathrm{mg} \mathrm{l}^{-1} \mathrm{NaCl}$, Micropur katadyn, Wallisellen, Switzerland) to prevent microbial growth. The samples were kept cool and transported to a nearby field laboratory. Additionally, all leaves distal to the branch segment were harvested. In the laboratory, each branch segment was recut under water with a razor blade and mounted on the tubing system. We used distilled water containing the same sodium-silver-chloride complex as described above for the conductivity measurements. Before entering the branch segment, the solution was forced through a $0.2 \mu \mathrm{m}$ membrane filter (Maxi Capsule, Pall, USA). Hydraulic conductivity $\left(k_{\mathrm{h}}\right)$ was measured three times across a $0.006 \mathrm{MPa}$ pressure gradient, and after the first and second measurement segments were flushed at a pressure of $0.12 \mathrm{MPa}$ to remove native emboli and to determine maximal hydraulic conductivity for further calculations. Subsequently, length and mean diameter of the segments were determined and the samples stored in $70 \%$ ethanol for further anatomical analyses. Hydraulic conductivity $\left(k_{\mathrm{h}}, \mathrm{kg} \mathrm{m} \mathrm{MPa}^{-1} \mathrm{~s}^{-1}\right)$ was measured as:

$k_{\mathrm{h}}=J_{v} \frac{\Delta P}{\Delta X}$

where $J_{v}$ is the flow rate through the branch segment $\left(\mathrm{kg} \mathrm{s}^{-1}\right)$ and $\Delta P / \Delta X$ is the pressure gradient across the segment $\left(\mathrm{MPa} \mathrm{m}^{-1}\right)$. $k_{\mathrm{h}}$ was used to calculate sapwoodarea specific $\left(k_{\mathrm{S}}\right)$ and leaf area-specific conductivity $\left(k_{\mathrm{L}}\right.$, $\mathrm{kg} \mathrm{m}^{-1} \mathrm{MPa}^{-1} \mathrm{~s}^{-1}$ ) by dividing the maximum conductivity by the microscopically determined xylem cross-sectional area without pith and bark $\left(\mathrm{m}^{2}\right)$ or the supported leaf area $\left(\mathrm{m}^{2}\right)$ of the branch segments. 


\subsection{Xylem anatomy, vessel size distribution and theoretical hydraulic conductivity}

Anatomical measurements were conducted in all harvested branch segments and trunk cores. We used a stereomicroscope (SteREO V20, Carl Zeiss MicroImaging GmbH, Germany) to obtain high-quality top-view images of the cross-sectional cuts of the branches and trunk cores. Before analysis, the branch segments and trunk cores were dyed with safranin and treated with chalk. The base of every branch segment was photographed to calculate total sapwood area $\left(A_{\text {Xylem }}, \mathrm{m}^{2}\right)$ in order to derive values of sapwoodspecific conductivity $\left(k_{\mathrm{S}}\right)$. From a subsample of 30 suncanopy branch segments harvested on 10 trees, the radius from pith to bark was determined with the software ImageJ (v1.44p, http://rsb.info.nih.gov/ij) to exempt the outermost radial quart of the branch sapwood. We assumed that this outermost radial section of the sapwood (i.e. $1.01 \pm 0.02 \mathrm{~mm}$ in our sample) must have been produced during the 24 months before harvest, i.e. under the influence of the drought treatment. This outermost area of the digital top-view images $\left(25.91 \pm 1.25 \mathrm{~mm}^{2}\right)$ was exempted for further analysis with the software Adobe Photoshop (CS2, Version 9.0, Adobe Systems Incorporated, USA).

From the trunk core samples, we analyzed only the outermost centimeter of the sapwood (on average, an area of $45.3 \pm 1.3 \mathrm{~mm}^{2}$ ), again assuming that it had been produced during the experimental drought period; this assumption is supported by the stem increment data.

The images were analyzed with the software ImageJ using the particle analysis-function to estimate individual and cumulative vessel lumen areas $\left(A_{\text {Lumen }}, \mathrm{m}^{2}\right)$, vessel density $\left(\mathrm{VD}, \mathrm{n} \mathrm{mm}^{-2}\right.$ ), and idealized vessel diameters $(d)$ from major (a) and minor (b) vessel radii using the equation given by White (1991):

$d=\left(\frac{32 \cdot(a \cdot b)^{3}}{a^{2} \cdot b^{2}}\right)^{\frac{1}{4}}$

The diameters $(d)$ of individual vessels were used to calculate the hydraulic mean diameter $\left(d_{\mathrm{h}}\right)$ according to Sperry et al. (1994):

$d_{\mathrm{h}}=\frac{\sum d_{i}^{5}}{\sum d_{i}^{4}}$

By this transformation, every vessel is weighted according to its contribution to total hydraulic conductivity. According to the Hagen-Poiseuille equation, theoretical hydraulic conductivity $\left(k_{\mathrm{h}}^{\text {theo }}, \mathrm{m}^{4} \mathrm{MPa}^{-1} \mathrm{~s}^{-1}\right)$ was calculated as:

$k_{\mathrm{h}}^{\text {theo }}=\frac{\pi \Sigma r^{4}}{8 \eta}$

In this expression, the viscosity of water $(\eta)$ at $20^{\circ} \mathrm{C}(1.002 \times$ $10^{-3} \mathrm{Pas}$, Zwieniecki et al., 2001) was used. $k_{\mathrm{h}}^{\text {theo }}$ served to calculate theoretical sapwood-area specific conductivity $\left(k_{\mathrm{s}}^{\text {theo }}, \mathrm{kg} \mathrm{m}^{-1} \mathrm{MPa}^{-1} \mathrm{~s}^{-1}\right)$ by dividing by cumulative sapwood area $\left(A_{\text {Xylem }}\right)$ and multiplying $k_{\mathrm{s}}^{\text {theo }}$ with the density of water $(\rho)$ at $20^{\circ} \mathrm{C}\left(998.20 \mathrm{~kg} \mathrm{~m}^{-3}\right.$, James et al., 2003):

$k_{\mathrm{s}}^{\text {theo }}=\frac{k_{\mathrm{h}}^{\text {theo }} \cdot \rho}{A_{\text {Xylem }}}$

\subsection{Leaf morphology and nutrient analyses}

All leaves distal to the analyzed branch segments were stripped off and analyzed for their leaf area (WinFOLIA 2005b, Regent Instruments Inc.). On average, 101.7 \pm 5.0 leaves per branch segment (control $n=56$, drought $n=60$ ) were scanned to obtain fresh leaf area per branch segment and mean leaf size $\left(L, \mathrm{~cm}^{2}\right)$. After scanning, the leaves were dried to constant mass at $70^{\circ} \mathrm{C}$ and weighed on a laboratory precision balance. Specific leaf area (SLA, $\mathrm{cm}^{2} \mathrm{~g}^{-1}$ ) was calculated as fresh leaf area divided by dry leaf mass, the Huber value (HV) was calculated as sapwood crosssectional area divided by fresh leaf area. The specific leaf number stands for the number of leaves supported by a given area of xylem per branch, which was calculated by dividing the total number of leaves distal to the branch segment by the branch cross-sectional area $\left(n_{\mathrm{L}}^{\mathrm{spec}}, \mathrm{n} \mathrm{mm}^{-2}\right)$. Stomatal density (SD) was counted on the lower side of three leaves per tree using nail polish pull-offs photographed at $25 \times$ or $100 \times$ magnification that were investigated under a light microscope (DM5000B, Leica Microsystems, Wetzlar, Germany) equipped with a digital camera (DFC 300FX, Leica Microsystems, Wetzlar, Germany). Foliar concentrations of $\mathrm{C}, \mathrm{N}, \mathrm{P}$ and $\mathrm{Ca}, \mathrm{K}, \mathrm{Mg}, \mathrm{Fe}$ and $\mathrm{Mn}$ were analyzed by ICP analysis (Optima 5300 DV, PerkinElmer Inc., USA) and expressed on a mass and leaf area basis ( $\operatorname{control} n=56$, drought $n=63$ ). The foliar signatures of $\delta^{13} \mathrm{C}$ and $\delta^{18} \mathrm{O}$ in the leaf bulk tissue were determined with a Delta plus isotope mass spectrometer (Finnigan MAT, Bremen, Germany), a Conflo III interface (Thermo Electron Coorperation, Bremen, Germany) and a NA2500 elemental analyzer (CE-Instruments, Rodano, Milano, Italy) using standard $\delta$ notion:

$\delta=\left(R_{\text {sample }} / R_{\text {standard }}-1\right) \cdot 1000(\% o)$

\subsection{Statistical analyses}

Restricted canopy access resulted in a nested sampling design at the branch level. Thus, branch hydraulic, anatomical and leaf-related variables were tested for significant differences between the drought and control treatments with linear mixed effects models with treatment as a fixed variable. We assumed the non-independence of different branches and leaves within a tree, and of different trees within the plots in the models by adding plot and tree nested in plot as random effects. Linear mixed effects models were also applied in the analysis of stem increment data and morphological 


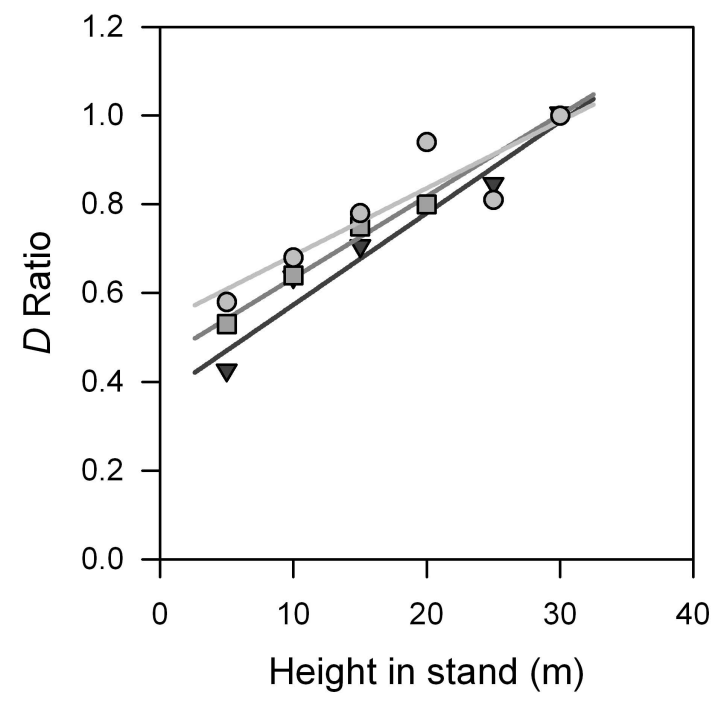

Fig. 1. Increase in mean vapor pressure deficit $(D$, relative units, $30 \mathrm{~m}=1.0$ ) with height in the forest. Regression lines and symbols correspond to three different vertical profiles. Points are mean values for continuous measurements over a period of 12 days in June 2009.

and anatomical traits related to trunk wood. These calculations were conducted with the software package $\mathrm{R}$, linear regressions with the software Xact 8.03 (SciLab, Hamburg, Germany). When comparing upper and lower canopy of the trees in a given treatment, the analyses are labeled with "canopy position", when comparing either upper canopy or lower canopy data between the drought and control plots, the label "treatment" is used.

\section{Results}

\subsection{Microclimatic conditions}

During the 24-month study period, mean monthly precipitation was $228 \pm 26 \mathrm{~mm}$. In the first year (1 May 2007 to 30 April 2008) and second year (1 May 2008 to 30 April 2009) of the experiment, annual precipitation was 3156 and $2309 \mathrm{~mm} \mathrm{yr}^{-1}$, respectively. The mean daily maximum $D$ was $1.3 \mathrm{kPa}$, mean daily $T 20.8^{\circ} \mathrm{C}$, and mean daily $R$ 13.4 $\mathrm{MJ} \mathrm{m}^{-2} \mathrm{~d}^{-1}$. No seasonality in $T$ or $\mathrm{RH}$ was observed during the two years (Table 1). The vertical transect measurement campaign inside the forest showed a linear increase in the saturation deficit from the forest floor to canopy height with a doubling of $D$ (Fig. 1, regression equation: $D=0.45+0.018 \cdot$ height with $D$ in $\mathrm{kPa}$ and height expressed as a fraction of canopy height).

\subsection{Soil moisture status during the throughfall exclusion experiment}

The drying of the soil in the 24-month experiment proceeded in two steps reflecting the roof closure by $50 \%$ in the period May 2007-January 2008 and subsequently by $80 \%$ from February 2008 to May 2009. While volumetric soil moisture $\theta$ was reduced by ca. $5 \%$ in the drought plots compared to the control in the first period $(0.0-0.5 \mathrm{~m}$ and $0.5-3.0 \mathrm{~m}$ soil depth), $\theta$ was reduced by more than $10 \%$ in the upper soil and ca. $7 \%$ in the lower soil in the second period (Fig. 2). Heavy rainfall resulted in limited recharge of the soil water reserves in the upper soil in the first phase during incomplete roof closure, and $\theta$ remained fairly constant at $0.0-$ $0.5 \mathrm{~m}$ and $0.5-3.0 \mathrm{~m}$ depth under the more efficient drought exposure in the experiment's second phase. The lowest $\theta$ values were reached shortly before the re-opening of the roof in May 2009. When expressed in relation to the control plots, $\theta$ was reduced by ca. $30 \%$ in the upper and $15 \%$ in the lower profile in the period June 2008-May 2009.

According to the soil water retention curves, calculated $\Psi_{\text {soil }}$ decreased in the topsoil $(0.1 \mathrm{~m})$ up to $-3 \mathrm{MPa}$ during the driest phase from March 2009 until roof opening. As an average for the three investigated upper soil layers $(0.1$, 0.2 and $0.4 \mathrm{~m}), \Psi_{\text {soil }}$ dropped to $-1.5 \mathrm{MPa}$ at the end of the desiccation period (Fig. 2). In contrast, no significant differences in $\Psi_{\text {soil }}$ were detected in the lower soil layers $(0.75,1.5$ and $2.5 \mathrm{~m}$ ) between drought and control plots, even though $\theta$ differed by about $15 \%$.

The calculated relative extractable water for the upper soil layers $\left(\mathrm{REW}_{\text {top }}\right)$ dropped below the threshold value of 0.4 in the drought plots immediately after the beginning of the second phase of the desiccation in early 2008, enhanced by rather low rainfall in this period (Fig. 2). Interrupted by a short recovery due to strong rainfall in March/April 2008, $\mathrm{REW}_{\text {top }}$ decreased by $90 \%$ in the drought plots. On the other hand, the relative extractable water of the lower soil layers $\left(\mathrm{REW}_{\text {low }}\right)$ dropped below the threshold of 0.4 only during the driest phase of the experiment from February 2009 onwards. Nevertheless, $\mathrm{REW}_{\text {low }}$ decreased by $50 \%$ in the drought plots from June 2008 until May 2009.

\subsection{Differences between sun and shade canopy}

The large majority of leaf morphological, chemical and branch hydraulic traits differed significantly between the sunlit upper canopy and the lower shade canopy of $C$. acuminatissima (Table 6). Sun leaves were ca. $40 \%$ smaller with 15-25\% lower SLA and 10\% higher stomatal density (Table 3). Sun leaves also had less negative $\delta^{13} \mathrm{C}$, and generally showed higher foliar nutrient concentrations per leaf area (except for $\mathrm{Mg}$ and $\mathrm{Fe}$ ) than shade leaves, while the nutrient concentrations per mass were not different (except for higher $\mathrm{Mg}$ and lower Mn concentrations in sun leaves from the control trees). Shade leaves with lower $\mathrm{N}$ per leaf 
Table 3. Hydraulic properties of the branch xylem, leaf morphological traits and branch wood density in the sun and shade canopy of $C$. acuminatissima. Leaf-specific conductivity $\left(k_{\mathrm{L}}\right)$, sapwood-specific conductivity $\left(k_{\mathrm{S}}\right)$, Huber value (HV), specific leaf area (SLA), leaf size $(L)$, stomatal density $(\mathrm{SD})$, and branch wood density $\left(\rho_{\text {branch }}\right)$. Given are means \pm SE per treatment $(n=7)$. For within-tree replicates see Material and Methods.

\begin{tabular}{lrrrr}
\hline & \multicolumn{2}{c}{ Sun canopy } & \multicolumn{2}{c}{ Shade canopy } \\
\cline { 2 - 5 } & \multicolumn{1}{c}{ Control } & \multicolumn{1}{c}{ Drought } & \multicolumn{1}{c}{ Control } & \multicolumn{1}{c}{ Drought } \\
\hline Hydraulic traits & & & \\
\hline$k_{\mathrm{S}}\left(\mathrm{kg} \mathrm{m}^{-1} \mathrm{MPa}^{-1} \mathrm{~s}^{-1}\right)$ & $17.0 \pm 1.3$ & $12.3 \pm 1.6$ & $18.8 \pm 2.1$ & $14.1 \pm 1.9$ \\
$k_{\mathrm{L}}\left(10^{-3} \mathrm{~kg} \mathrm{~m}^{-1} \mathrm{MPa}^{-1} \mathrm{~s}^{-1}\right)$ & $7.1 \pm 0.9$ & $8.8 \pm 4.1$ & $4.8 \pm 0.7$ & $3.4 \pm 0.8$ \\
$\mathrm{HV}\left(10^{-4} \mathrm{~cm}^{2} \mathrm{~cm}^{-2}\right)$ & $4.5 \pm 1.0$ & $6.3 \pm 2.1$ & $2.5 \pm 1.9$ & $2.4 \pm 3.7$ \\
$n_{\mathrm{L} p e c}\left(\mathrm{n} \mathrm{mm}^{-2}\right)$ & $1.8 \pm 0.2$ & $1.3 \pm 0.2$ & $1.7 \pm 0.2$ & $1.4 \pm 0.2$ \\
\hline Leaf morphology & & & & \\
\hline $\mathrm{SLA}\left(\mathrm{cm}^{2} \mathrm{~g}^{-1}\right)$ & $71.4 \pm 2.8$ & $67.8 \pm 3.4$ & $84.7 \pm 4.0$ & $88.2 \pm 6.4$ \\
$\left.L(\mathrm{~cm})^{2}\right)$ & $16.4 \pm 1.7$ & $22.4 \pm 1.1$ & $27.5 \pm 3.7$ & $38.4 \pm 2.8$ \\
SD $\left(\mathrm{n} \mathrm{mm}^{-2}\right)$ & $495.2 \pm 12.0$ & $510.7 \pm 16.8$ & $464.8 \pm 16.0$ & $446.7 \pm 10.3$ \\
\hline Wood density & & & & \\
\hline$\rho_{\text {branch }}\left(\mathrm{kg} \mathrm{m}^{-3}\right)$ & $547.6 \pm 15.4$ & $586.6 \pm 15.2$ & $531.0 \pm 25.8$ & $535.6 \pm 23.9$ \\
\hline
\end{tabular}

Table 4. Summary of means ( $\pm 1 \mathrm{SE}, n=5)$ of branch wood anatomical and hydraulic traits from the sun canopy of $C$. acuminatissima. Vessel lumen area $\left(A_{\text {Lumen }}\right)$, vessel density (VD), mean vessel diameter $(d)$, hydraulic mean vessel diameter $\left(d_{\mathrm{h}}\right)$, theoretical sapwood-specific conductivity $\left(k_{\mathrm{S}}\right)$ are shown.

\begin{tabular}{|c|c|c|c|}
\hline & \multicolumn{2}{|c|}{ Sun branches } & \multirow[b]{2}{*}{$p$} \\
\hline & Control & Drought & \\
\hline$A_{\text {Lumen }}(\%)$ & $0.09 \pm 0.01$ & $0.10 \pm 0.01$ & 0.604 \\
\hline $\mathrm{VD}\left(\mathrm{n} \mathrm{mm}^{-2}\right)$ & $20.85 \pm 2.53$ & $25.75 \pm 1.72$ & 0.131 \\
\hline$d(\mu \mathrm{m})$ & $70.49 \pm 3.11$ & $65.63 \pm 4.58$ & 0.338 \\
\hline$d_{\mathrm{h}}(\mu \mathrm{m})$ & $92.96 \pm 4.18$ & $85.83 \pm 5.63$ & 0.270 \\
\hline$k_{\mathrm{S}}^{\text {theo }}\left(\mathrm{kg} \mathrm{m}^{-1} \mathrm{MPa}^{-1} \mathrm{~s}^{-1}\right)$ & $21.54 \pm 2.95$ & $21.07 \pm 4.49$ & 0.921 \\
\hline$k_{\mathrm{L}}^{\text {theo }}\left(10^{-4} \mathrm{~kg} \mathrm{~m}^{-1} \mathrm{MPa}^{-1} \mathrm{~s}^{-1}\right)$ & $34.49 \pm 4.87$ & $60.65 \pm 37.25$ & 0.443 \\
\hline
\end{tabular}

area discriminated stronger against ${ }^{13} \mathrm{C}$ (more negative $\delta^{13} \mathrm{C}$ signature) than sun leaves (Tables 5 and 6). Sun canopy branches had 45-50\% larger Huber values and 33-47\% lower $k_{\mathrm{L}}$ than shade canopy branches, whereas $k_{\mathrm{S}}$ was similar among treatments. $\rho_{\text {branch }}$ was $10 \%$ higher in sun than in shade canopy branches in the drought plots (Tables 3 and 6).

\subsection{Effects of soil moisture deficits on hydraulic properties and leaf traits}

Sun canopy branches of $C$. acuminatissima harvested after the two-year soil desiccation period had significantly lower $k_{\mathrm{S}}$ values (reduction about $30 \%$ ) than samples from the control trees (Tables 3 and 6). However, wood anatomical mea-
Table 5. Isotope signatures of carbon $\left(\delta^{13} \mathrm{C}\right)$ and oxygen $\left(\delta^{18} \mathrm{O}\right)$ in leaf biomass and foliar contents of $\mathrm{C}, \mathrm{N}, \mathrm{P}$ and cations per mass and per leaf area in leaves that were harvested distal to the branch segments used for hydraulic measurements. Mean nutrient concentrations $( \pm 1 \mathrm{SE}, n=7)$ in $\mathrm{g} \mathrm{kg}^{-1}$ or $\mathrm{g} \mathrm{m}^{-2}$. For the level of significance $(p)$ of treatment differences see Table A5 in the Supplement.

\begin{tabular}{|c|c|c|c|c|}
\hline & \multicolumn{2}{|c|}{ Sun leaves } & \multicolumn{2}{|c|}{ Shade leaves } \\
\hline & Control & Drought & Control & Drought \\
\hline \multicolumn{5}{|c|}{ Isotope composition } \\
\hline$\delta^{13} \mathrm{C}$ & $-28.51 \pm 0.08$ & $-28.26 \pm 0.25$ & $-29.54 \pm 0.19$ & $-29.17 \pm 0.25$ \\
\hline$\delta^{18} \mathrm{O}$ & $19.14 \pm 0.09$ & $19.81 \pm 0.28$ & $18.86 \pm 0.19$ & $19.25 \pm 0.27$ \\
\hline \multicolumn{5}{|c|}{ Nutrient concentrations mass-related } \\
\hline $\mathrm{C}$ & $502.8 \pm 6.5$ & $494.4 \pm 4.2$ & $509.4 \pm 7.0$ & $489.1 \pm 4.1$ \\
\hline $\mathrm{N}$ & $18.03 \pm 0.62$ & $17.58 \pm 0.35$ & $18.15 \pm 0.40$ & $16.59 \pm 0.51$ \\
\hline $\mathrm{P}$ & $0.77 \pm 0.02$ & $0.77 \pm 0.04$ & $0.77 \pm 0.01$ & $0.78 \pm 0.04$ \\
\hline $\mathrm{Ca}$ & $5.00 \pm 0.41$ & $3.62 \pm 0.36$ & $4.86 \pm 0.36$ & $3.53 \pm 0.32$ \\
\hline $\mathrm{Fe}$ & $0.042 \pm 0.008$ & $0.031 \pm 0.005$ & $0.047 \pm 0.010$ & $0.030 \pm 0.006$ \\
\hline $\mathrm{K}$ & $4.87 \pm 0.21$ & $4.74 \pm 0.27$ & $5.00 \pm 0.24$ & $4.89 \pm 0.35$ \\
\hline $\mathrm{Mg}$ & $1.79 \pm 0.08$ & $1.43 \pm 0.12$ & $2.12 \pm 0.13$ & $1.87 \pm 0.09$ \\
\hline $\mathrm{Mn}$ & $0.63 \pm 0.07$ & $0.64 \pm 0.10$ & $0.52 \pm 0.05$ & $0.57 \pm 0.07$ \\
\hline \multicolumn{5}{|c|}{ Nutrient-concentrations area-related } \\
\hline $\mathrm{C}$ & $71.18 \pm 2.33$ & $74.06 \pm 3.56$ & $61.14 \pm 2.85$ & $58.76 \pm 3.50$ \\
\hline $\mathrm{N}$ & $2.55 \pm 0.13$ & $2.62 \pm 0.11$ & $2.18 \pm 0.10$ & $1.98 \pm 0.11$ \\
\hline $\mathrm{P}$ & $0.109 \pm 0.004$ & $0.115 \pm 0.006$ & $0.092 \pm 0.004$ & $0.094 \pm 0.004$ \\
\hline $\mathrm{Ca}$ & $0.71 \pm 0.07$ & $0.54 \pm 0.06$ & $0.58 \pm 0.04$ & $0.43 \pm 0.04$ \\
\hline $\mathrm{Fe}$ & $0.006 \pm 0.001$ & $0.005 \pm 0.001$ & $0.006 \pm 0.001$ & $0.003 \pm 0.001$ \\
\hline $\mathrm{K}$ & $0.69 \pm 0.03$ & $0.70 \pm 0.02$ & $0.59 \pm 0.02$ & $0.59 \pm 0.03$ \\
\hline $\mathrm{Mg}$ & $0.25 \pm 0.01$ & $0.21 \pm 0.02$ & $0.25 \pm 0.01$ & $0.23 \pm 0.02$ \\
\hline $\mathrm{Mn}$ & $0.09 \pm 0.01$ & $0.10 \pm 0.02$ & $0.06 \pm 0.01$ & $0.07 \pm 0.01$ \\
\hline
\end{tabular}



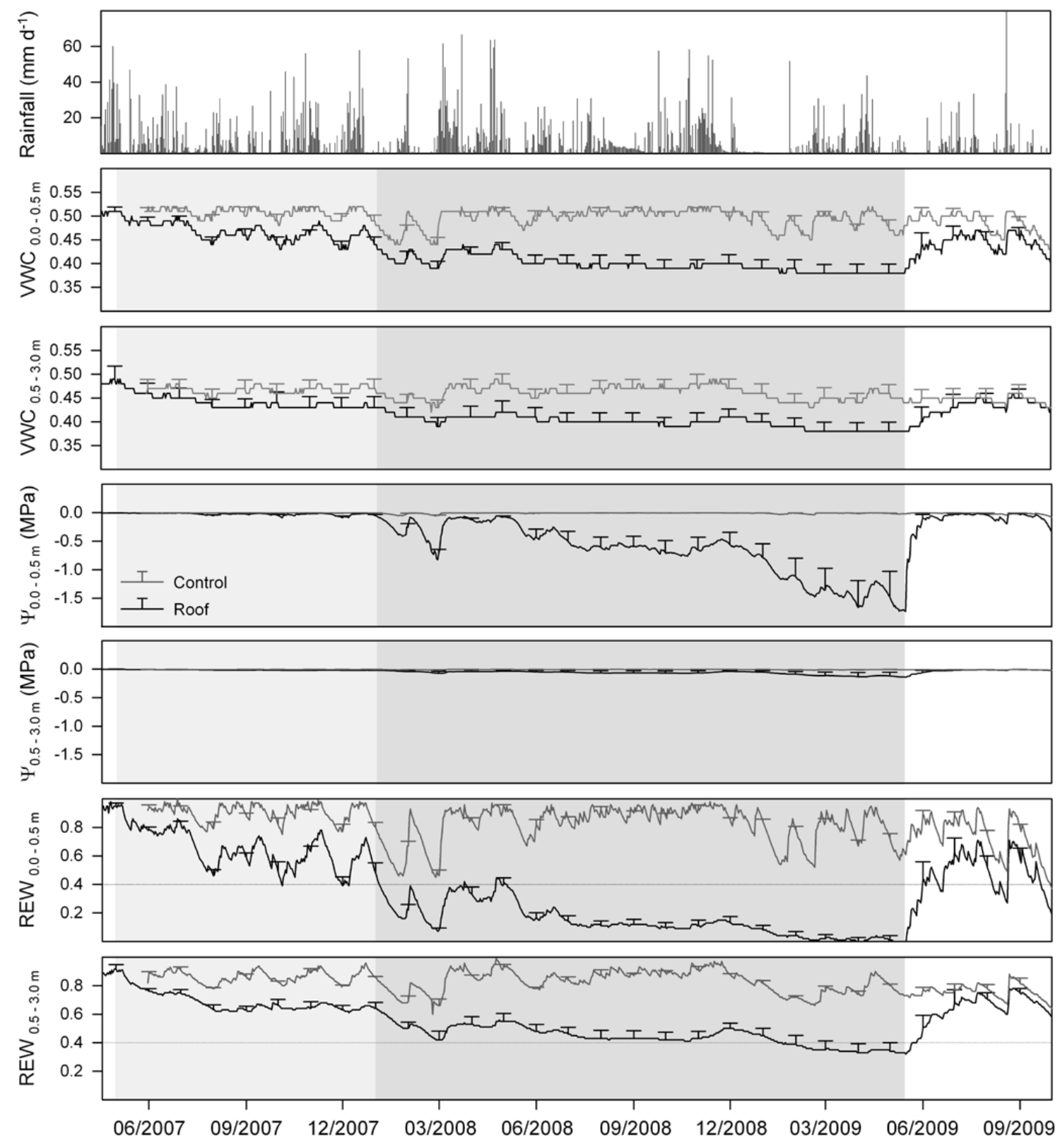

Fig. 2. Volumetric soil water content $(\theta)$, soil water potential $(\Psi)$ and relative extractable water (REW) of the control (grey line) and the drought (black line) plots during the 2-yr experimental period. Mean measuring depths are shown: upper layer $(0.0-0.5 \mathrm{~m})$, lower layer $(0.5-3.0 \mathrm{~m})$. Values are daily means $\pm 1 \mathrm{SE}$. The light grey area marks the first period of the experiment when $50 \%$ of the roof was closed. The dark grey area indicates the second period of the experiment with a roof closure of $80 \%$. The roof was opened again in May 2009.

surements of the outermost (most recent) sapwood of these sun canopy branches revealed no significant differences in vessel size and vessel density (Table 4). While Huber value did not differ significantly between treatments, we found a significant increase in leaf size by $27 \%$ in sun canopy branches (and a similar tendency in the shade crown) after two years of desiccation in the drought plots. Analysis of isotope composition in leaf dry mass indicated no drought effects on $\delta^{13} \mathrm{C}$ (Table 5). The $\delta^{13} \mathrm{C}-\mathrm{N}_{\mathrm{A}}$ relationship was not different between drought and control plots (data not shown), and no relation existed between foliar $\delta^{13} \mathrm{C}$ and $\delta^{18} \mathrm{O}$ in the drought plots (Fig. 4). Leaves harvested at the end of the experiment in the drought plots contained significantly less $\mathrm{Ca}, \mathrm{Mg}$ and $\mathrm{Fe}$ (sun and shade canopy) and $\mathrm{N}$ (shade canopy only) per dry mass than the control (Tables 5 and 6); the concentration reduction was largest for $\mathrm{Ca}$ (ca. $30 \%$ decrease). 


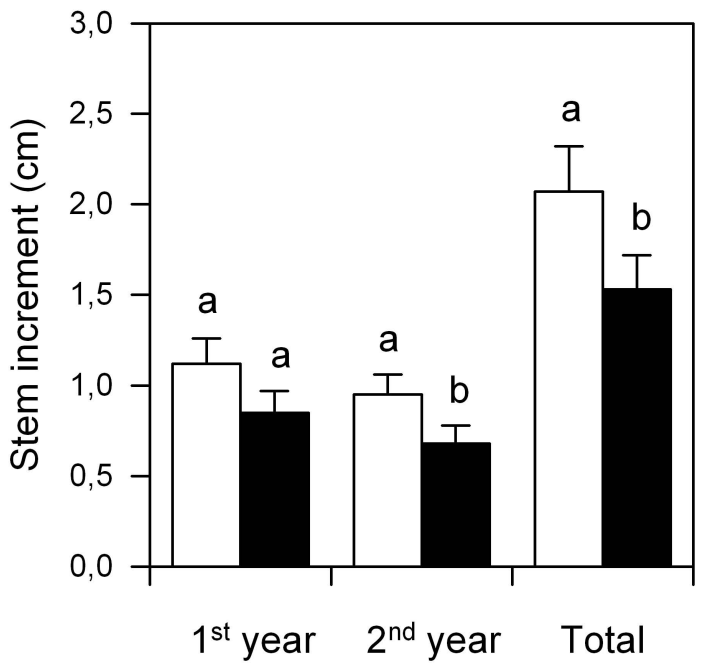

Fig. 3. Annual stem diameter increment (cm) for the first and second year, and for the whole desiccation period for C. acuminatissima trees from control $(\square, n=5)$ and drought $(\boldsymbol{\square}, n=9)$ plots. Values are means $\pm 1 \mathrm{SE}$. Small letters indicate significant differences between the two treatments $(p \leq 0.1)$.

\subsection{Stem increment, wood anatomy and wood density as affected by soil moisture deficits}

In the drought plots, we observed a (non-significant) tendency for a smaller annual stem diameter increment $(25 \%$ reduction) in the first year of the experiment, and a marginally significant decrease $(30 \%)$ in the second year $(p=0.08$, Fig. 3, Table A8 in the Supplement). Drought caused a significant reduction in saturated water content (SWC) of the stem xylem $(10 \%)$ and an increase in wood density (marginally significant, $p=0.07$, Table 2 , Table A7 in the Supplement).

\section{Discussion}

\subsection{Drought responses at leaf, branch and stem levels}

After 24 months of throughfall exclusion, the topsoil layers of the Pono forest were strongly desiccated, exceeding conventional thresholds of critical soil water availability for plant growth $\left(\psi_{\text {soil }}<-1.5 \mathrm{MPa}, \mathrm{REW}<0.4\right)$. In accordance with results from other root system studies in perhumid environments (Schenk and Jackson, 2002; Hertel et al., 2003; Jiménez et al., 2009), the trees of the Pono forest apparently did not develop deep-reaching roots that could tap water reserves in the subsoil. In fact, Hertel et al. (2009) observed that $74 \%$ of the fine root biomass $(d \leq 2 \mathrm{~mm})$ was located within the top $20 \mathrm{~cm}$ and only $4 \%$ reached $40-60 \mathrm{~cm}$ soil depth. Coarse roots $(d>2 \mathrm{~mm})$ showed a similar depth distribution $(91 \%$ in the top $20 \mathrm{~cm}, 1 \%$ in $40-60 \mathrm{~cm})$. Further, only low fine root densities $\left(0.12 \mathrm{~g}^{-1}\right)$ were located be-

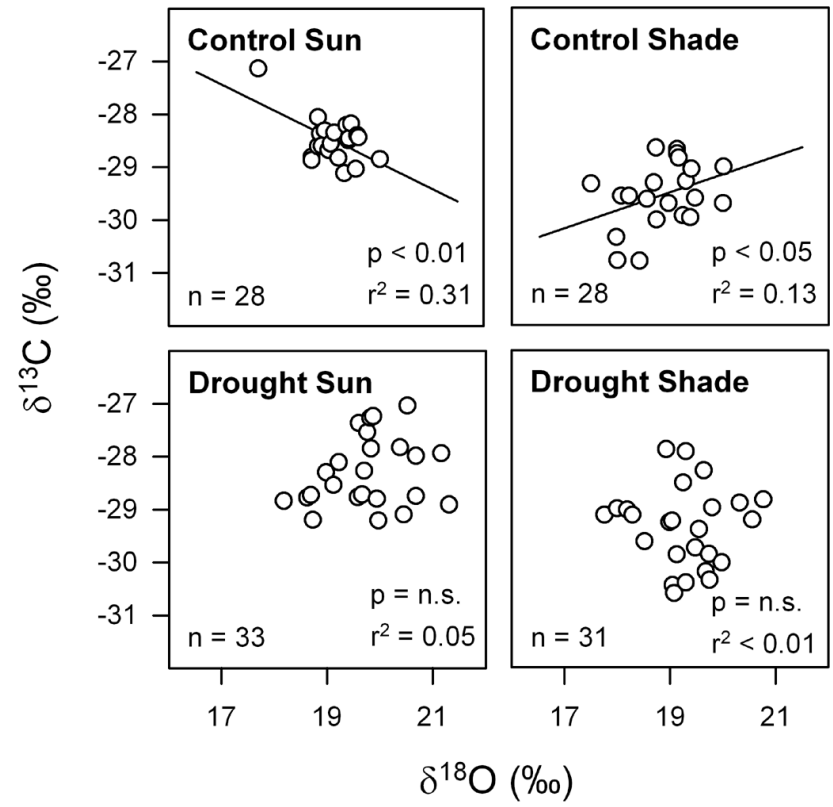

Fig. 4. Relation between isotope ratios of carbon and oxygen in control and drought-exposed trees, and in leaves from the sun and shade canopies.

tween 100-300 cm soil depths. These data suggest that deepreaching roots are far less important in this perhumid forest compared to many Amazonian forests that experience pronounced dry periods (Nepstad et al., 2002). We conclude that more than three months at water availabilities below the conventional "wilting point" in the topsoil must have exposed the studied trees to drought stress of considerable intensity.

Experimental determination of hydraulic conductivity in more than 100 sun- and shade-canopy branches of C. acuminatissima showed that terminal sun canopy branches of the desiccated trees had a $30 \%$ decreased sapwood-specific hydraulic conductivity $\left(k_{\mathrm{s}}\right)$ than the control trees under conditions of maximum conduit permeability (all cavitations removed by flushing), whereas leaf-specific conductivity did not differ significantly between treatments. It is likely that the imposed two-year soil drought resulted in the production of this low-conductivity sapwood with narrow vessels. In fact, the vessels in the youngest most distal sapwood of sun canopy branches had on average by $10 \%$ smaller diameters. However, these differences in vessel anatomy were not significant. Further support for drought-induced anatomical changes in the sun-canopy branch sapwood comes from the branch wood density data; $\rho_{\text {branch }}$ increased by approximately $10 \%$ during the drought $(p=0.07)$. However, this increase in $\rho_{\text {branch }}$ does not necessarily reflect a decrease in vessel size or increase in vessel density, but even so, we found a tendency for both. Wood density is rather closely linked to the amount of fibres and tracheids and thus to the physical stability of woody tissues during high negative 

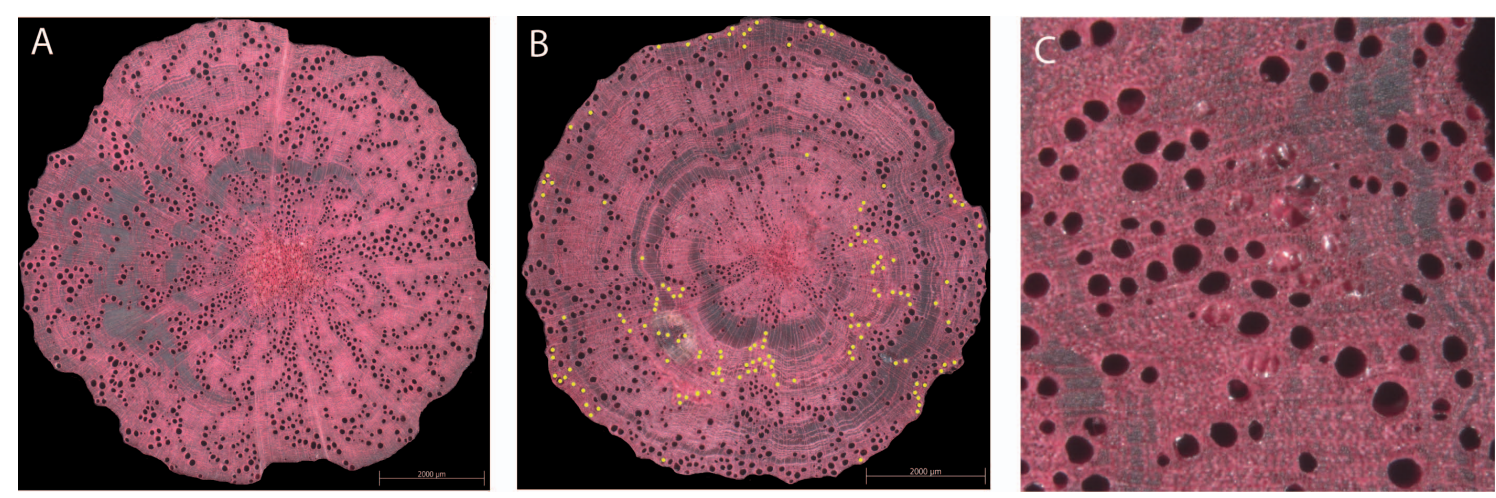

Fig. 5. Presence of tyloses in the vessels of branch xylem in the sun canopy of C. acuminatissima. (A) Control branch without tyloses, (B) drought-exposed branch with tyloses. Vessel occlusion marked with yellow spots. Many occluded vessels are located in the outermost recently produced sapwood, $(\mathbf{C})$ vessels in the outermost sapwood filled with tyloses from a drought-exposed sun canopy branch.

pressures caused by drought stress (Domec et al., 2009). Even though part of our results can only be interpreted as a non-significant tendency towards acclimation in the hydraulic system of $C$. acuminatissima, our observations agree with previous results from temperate forest species, which adjust the shape of their vessels when exposed to drought (e.g. Sass and Eckstein, 1995; Eilmann et al., 2006), reflecting the plant water status at the time of cell differentiation (Garcia-Gonzales and Eckstein, 2003). Another process that could have contributed to the observed decrease in branch $k_{\mathrm{S}}$ in the drought-exposed trees is irreversible vessel filling by tyloses (McElrone et al., 2010; Kitin et al., 2010). Microscopic inspection showed that tyloses were indeed present in vessels of drought-exposed sun-canopy branches (see Fig. 5), but we do not have quantitative data to test this possibility.

Surprisingly, in contrast to our second hypothesis, the sun-canopy branches of $C$. acuminatissima had significantly larger leaves (by $30 \%$ ), and not smaller as anticipated, in the drought plots at the end of the experiment compared to the control. However, the larger leaf size was compensated by fewer leaves (average decrease by $28 \%$ per cross-sectional area relative to the control), i.e. total branch leaf area actually decreased. Thus, the remaining leaf buds may have profited from the reduced transpiration loss allowing them to develop larger leaves despite the unfavourable soil moisture status. Reducing the number of leaves in order to maintain, or even improve, the water status of later developed leaves may be more beneficial for canopy carbon gain than down-regulating stomatal conductance. A similar effect was observed in saplings of silver birch (Betula pendula) that produced fewer, but larger leaves under drought conditions (Aspelmeier and Leuschner, 2006). A relatively favourable leaf water status of the recently produced drought-exposed leaves is also indicated by the similar $\delta^{13} \mathrm{C}$ signature of leaf mass of $C$. acuminatissima trees in the drought and control plots, suggesting that stomatal conductance did not decline in droughted trees. If reduced stomatal conductance had been reduced, $\delta^{13} \mathrm{C}$ and $\delta^{18} \mathrm{O}$ should be positively correlated (Scheidegger et al., 2000; Cullen et al., 2008), which was not evident in our data.

Further in contrast to our second hypothesis, droughted trees did not exhibit reduced foliar nutrient concentrations, as has been found previously (e.g. Gessler et al., 2004; Beier et al., 2008; Fotelli et al., 2009; Kreuzwieser and Gessler, 2010). Neither foliar N nor P were considerably reduced after 24 months of drought treatment. However, significantly smaller leaf $\mathrm{Ca}$ contents per dry mass and also per leaf area may indicate either reduced transpiration rates or smaller $\mathrm{Ca}$ concentrations in the soil solution of the drought plots. This is because $\mathrm{Ca}$ is transported passively with the mass-flow of water in soil and xylem (Gollan et al., 1992; McDonald and Davis, 1996). Herbette and Cochard (2010) further found Ca to be a major determinant of xylem vulnerability to cavitation.

Radial increment was reduced by $30 \%$ in the droughtexposed trees in the second year of the experiment $(p=$ 0.08 ). This growth reduction was linked to a significant increase in wood density and a reduction in saturated water content in the trunk. In contrast to the sun-canopy branches, vessel diameter and density in trunk wood did not respond to the drought. These observations indicate that although the cambial activity (i.e. growth) of the stem is drought-sensitive in C. acuminatissima, reduction in cambial activity is not necessarily correlated with reduced vessel width or conductivity. Furthermore, it appears that drought-induced adaptive responses in xylem anatomy and hydraulics occur earlier in sun canopy branches where axial conductivity is lowest, and occur later in the trunk.

\subsection{Drought susceptibility of sun and shade canopy and the role of atmospheric moisture}

All investigated leaf morphological properties and hydraulic traits (except for $k_{\mathrm{S}}$ ) differed significantly between the sun and shade canopy leaves. Shade leaves of $C$. acuminatissima 
Table 6. P-values of a linear mixed effects model on significant differences between control and drought plots (Treatment) or sun and shade crown (Canopy position) in C. acuminatissima for 25 morphological, chemical and functional variables investigated. The labels denote Sun Control (SuC), Shade Control (ShC), Sun Drought $(\mathrm{SuD})$ and Shade Drought $(\mathrm{ShD})$. Significant differences $(p \leq 0.05)$ are printed in bold.

\begin{tabular}{|c|c|c|c|c|}
\hline & \multicolumn{2}{|c|}{ Treatment } & \multicolumn{2}{|c|}{ Canopy position } \\
\hline & SuC vs. SuD & ShC vs. ShD & $\mathrm{SuC}$ vs. ShC & SuD vs. $\mathrm{ShD}$ \\
\hline \multicolumn{5}{|c|}{ Hydraulic traits } \\
\hline$k_{\mathrm{S}}$ & 0.035 & 0.130 & 0.139 & 0.207 \\
\hline$k_{\mathrm{L}}$ & 0.644 & 0.162 & 0.009 & 0.005 \\
\hline HV & 0.390 & 0.561 & 0.002 & 0.001 \\
\hline$n_{\mathrm{L}}^{\text {spec }}$ & 0.132 & 0.245 & 0.444 & 0.301 \\
\hline \multicolumn{5}{|c|}{ Leaf morphology } \\
\hline SLA & 0.379 & 0.524 & $<0.001$ & $<\mathbf{0 . 0 0 1}$ \\
\hline $\mathrm{L}$ & 0.025 & 0.111 & $<0.001$ & $<0.001$ \\
\hline SD & 0.585 & 0.923 & 0.026 & $<\mathbf{0 . 0 0 1}$ \\
\hline \multicolumn{5}{|c|}{ Wood density } \\
\hline$\rho_{\text {branch }}$ & 0.072 & 0.916 & 0.353 & $<.0001$ \\
\hline \multicolumn{5}{|c|}{ Isotope composition } \\
\hline$\delta^{13} \mathrm{C}$ & 0.285 & 0.249 & $<0.001$ & $<0.001$ \\
\hline$\delta^{18} \mathrm{O}$ & 0.027 & 0.208 & 0.108 & 0.004 \\
\hline \multicolumn{5}{|c|}{ Nutrient concentrations mass-related } \\
\hline $\mathrm{C}$ & 0.217 & 0.128 & 0.277 & $<0.001$ \\
\hline $\mathrm{N}$ & 0.455 & 0.042 & 0.800 & $<0.001$ \\
\hline $\mathrm{P}$ & 0.894 & 0.568 & 0.833 & 0.608 \\
\hline $\mathrm{Ca}$ & 0.017 & 0.012 & 0.438 & 0.298 \\
\hline $\mathrm{Fe}$ & 0.226 & 0.194 & 0.345 & 0.857 \\
\hline K & 0.648 & 0.796 & 0.315 & 0.251 \\
\hline $\mathrm{Mg}$ & 0.016 & 0.122 & $<0.001$ & $<\mathbf{0 . 0 0 1}$ \\
\hline $\mathrm{Mn}$ & 0.931 & 0.493 & $<0.001$ & 0.041 \\
\hline \multicolumn{5}{|c|}{ Nutrient concentrations area-related } \\
\hline $\mathrm{C}$ & 0.443 & 0.543 & $<0.001$ & $<0.001$ \\
\hline $\mathrm{N}$ & 0.643 & 0.179 & $<0.001$ & $<0.001$ \\
\hline $\mathrm{P}$ & 0.245 & 0.612 & $<0.001$ & $<\mathbf{0 . 0 0 1}$ \\
\hline $\mathrm{Ca}$ & 0.057 & 0.024 & $<0.001$ & $<\mathbf{0 . 0 0 1}$ \\
\hline $\mathrm{Fe}$ & 0.333 & 0.200 & 0.979 & 0.254 \\
\hline $\mathrm{K}$ & 0.662 & 0.770 & $<0.001$ & $<0.001$ \\
\hline $\mathrm{Mg}$ & 0.074 & 0.344 & 0.839 & 0.184 \\
\hline $\mathrm{Mn}$ & 0.677 & 0.358 & $<0.001$ & $<\mathbf{0 . 0 0 1}$ \\
\hline
\end{tabular}

were on average $60-70 \%$ larger than sun leaves, their $\delta^{13} \mathrm{C}$ signature was more negative, and $k_{\mathrm{L}}$ and Huber values of shade shoots were about $40-60 \%$ lower than sun shoots, likely reflecting a lower evaporative demand. The decrease in ${ }^{13} \mathrm{C}$ discrimination along the shade-to-sun canopy gradient indicates that stomatal limitation of photosynthesis increases with height in tall trees, which also correlated with increasing atmospheric saturation deficit (see Fig. 1) and hydraulic resistance (e.g. Ambrose et al., 2009; Mullin et al., 2009; Oldham et al., 2010). This confirms our third hypothesis that the sun canopy of tall trees would be more drought-susceptible than lower crown parts, despite the perhumid climate. Indeed, the two traits exhibiting the highest drought sensitivity, sapwood-specific conductivity and leaf size, were only significantly different for the sun canopy branches between the drought and control treatments.

Integrating the results from the leaf and branch levels with those from the trunk, C. acuminatissima responds to drought conditions in two ways, one exhibited by growth reduction (stem radial growth) and secondly through acclimation (reductions in leaf area and sapwood-specific conductivity of sun-canopy branches). The adaptive responses are suited to lower the risk of cavitation and, possibly, to reduce canopy transpiration.

Since we observed no drought-induced mortality in our experiment, one might conclude that this tall species is not as drought-sensitive as initially expected. However, several facts make it likely that this conclusion is premature. First, other throughfall exclusion experiments in tropical and temperate forests showed that severe damage to the trees may occur only after two or more years of soil drought. For example, Nepstad et al. (2007) observed increased mortality of large trees in the Tapajós throughfall exclusion experiment only after four years, and da Costa et al. (2010) in the Caxiunana experiment after seven years. Thus, a considerable lag phase in the response of tall trees seems to be characteristic and our two-year experiment may not have been long enough to damage the trees critically. Second, although all throughfall exclusion experiments may be able to reduce soil moisture to a critical level, they cannot manipulate air humidity at canopy height. Clearly, during a natural ENSO-related drought trees would be exposed to a much higher evaporative demand than simulated in our experiment, where RH did not drop below $88 \%$. Trees further may profit from the frequent occurrence of canopy surface wetness by a decrease in transpiration and foliar uptake of water, thereby mitigating the effects of soil water shortage. It has been shown that several tropical trees can absorb water through the leaf cuticle (e.g. Yates and Hutley, 1995; Diaz and Granadillo, 2005; Oliveira et al., 2005). Given that the leaves of a nearby premontane perhumid forest were moist $45-55 \%$ of the time from rainfall interception or dew during a rainy period (Dietz et al., 2007), we speculate that canopy wetness and high air humidity are relevant factors to improve the water status of the trees in the studied forest. Hence, it is likely that soil desiccation in the course of a natural drought event will have a much stronger effect on tall trees of $C$. acuminatissima than was simulated in our experiment.

\section{Conclusions}

The Sulawesi Throughfall Exclusion Experiment represents the first simulated drought experiment conducted in a perhumid rainforest where natural droughts occur only occasionally. The shallow distribution of fine and coarse roots in this 
forest is thought to be resulting from the continuously high rainfall and permanently low atmospheric saturation deficit. These hydrologic characteristics make a distinction between the Sulawesi experiment and the two established throughfall exclusion experiments in Eastern Amazonia, where regular dry periods occur and several tree species possess deepreaching roots (Markewitz et al., 2010).

While no signs of canopy dieback or other critical damages were observed in $C$. acuminatissima after two years of throughfall reduction, the long and severe drought in the upper soil profile prompted a number of medium- to longterm responses at the leaf, branch and trunk levels that may have helped to reduce the trees' drought susceptibility, but these responses also suggest this species may be vulnerable to drought. We found sapwood-specific conductivity (branch xylem), sun-canopy leaf size and leaf numbers, and stem diameter growth to be particularly sensitive traits, while vessel dimensions and vessel density responded only little. Additionally, we found that the sun canopy of $C$. acuminatissima showed a more pronounced drought response than the shade crown, suggesting that tall trees with a large sun canopy are particularly vulnerable to drought stress. We assume that the constant high humidity in this tropical environment, which was not reduced by the throughfall exclusion, likely buffers damages that might otherwise be expected from low soil water availability.

\section{Supplementary material related to this article is available online at: http://www.biogeosciences.net/8/2179/2011/ bg-8-2179-2011-supplement.pdf.}

Acknowledgements. This study was conducted in the framework of the joint Indonesian-German Collaborative Research Center "Stability of Tropical Rainforest Margins, Indonesia (STORMA)" funded by the German Science Foundation (SFB 552). The authors thank Heike Culmsee for tree species identification, Yann Clough for statistical advice, Wolfram Lorenz for organizing the logistics in Palu, our Indonesian counterparts, the Indonesian Research Foundation LIPI, the authorities of the Lore Lindu National Park for the research permission and Anthony Ambrose and Sean Gleason for their constructive and helpful comments on an earlier version of the manuscript.

Edited by: R. Duursma

\section{References}

Aldrian, E. and Susanto, R. D.: Identification of three dominant rainfall regions within Indonesia and their relationship to sea surface temperature, Int. J. Climatol., 23, 1435-1452, 2003.

Aldrian, E., Dumenil-Gates, L., Jacob, D., Podzun, R., and Gunawan, D.: Long-term simulation of Indonesian rainfall with the MPI regional model, Clim. Dynam., 22, 795-814, 2004.

Allen, C. D., Macalady, A. K., Chenchouni, H., Bachelet, D., McDowell, N., Vennetier, M., Kitzberger, T., Rigling, A., Breshears,
D. D., Hogg, E. H., Gonzalez, P., Fensham, R., Zhang, Z., Castro, J., Demidova, N., Lim, J. H., Allard, G., Running, S. W., Semerci, A., and Cobb, N.: A global overview of drought and heatinduced tree mortality reveals emerging climate change risks for forests, Forest Ecol. Manag., 259, 660-684, 2010.

Ambrose, A. R., Sillett, S. C., and Dawson, T. E.: Effects of tree height on branch hydraulics, leaf structure and gas exchange in California redwoods, Plant Cell Environ., 32, 743-757, 2009.

Ambrose, A. R., Sillett, S. C., Koch, G. W., Van Pelt, R., Antoine, M. E., and Dawson, T. E.: Effects of height on treetop transpiration and stomatal conductance in coast redwood (Sequoia sempervirens), Tree Physiol., 30, 1260-1272, 2010.

Aspelmeier, S. and Leuschner, C.: Genotypic variation in drought response of silver birch (Betula pendula Roth): leaf and root morphology and carbon partitioning, Trees-Struct. Funct., 20, 42-52, 2006.

Awad, H., Barigah, T., Badel, E., Cochard, H., and Herbette, S.: Poplar vulnerability to xylem cavitation acclimates to drier soil conditions, Physiol. Plantarum, 139, 280-288, 2010.

Bates, B. C., Kundzewicz, Z. W., Wu, S. and Palutikof, J. P. (Eds.): Climate Change and Water, Technical Paper of the Intergovernmental Panel on Climate Change, IPCC Secretariat, Geneva, 210 pp., 2008.

Beier, C., Emmett, B. A., Penuelas, J., Schmidt, I. K., Tietema, A., Estiarte, M., Gundersen, P., Llorens, L., Riis-Nielsen, T., Sowerby, A., and Gorissen, A.: Carbon and nitrogen cycles in European ecosystems respond differently to global warming, Sci Total Environ., 407, 692-697, 2008.

Blackman, C. J., Brodribb, T. J., and Jordan, G. J.: Leaf hydraulic vulnerability is related to conduit dimensions and drought resistance across a diverse range of woody angiosperms, New Phytol., 188, 1113-1123, 2010.

Borchert, R. and Pockman, W. T.: Water storage capacitance and xylem tension in isolated branches of temperate and tropical trees, Tree Physiol., 25, 457-466, 2005.

Breda, N., Huc, R., Granier, A., and Dreyer, E.: Temperate forest trees and stands under severe drought: a review of ecophysiological responses, adaptation processes and long-term consequences, Ann. For. Sci., 63, 625-644, 2006.

Cai, J. and Tyree, M. T.: The impact of vessel size on vulnerability curves: data and models for within-species variability in saplings of aspen, Populus tremuloides Michx, Plant Cell Environ., 33, 1059-1069, 2010.

Cavaleri, M. A., Oberbauer, S. F., Clark, D. B., Clark, D. A., and Ryan, M. G.: Height is more important than light in determining leaf morphology in a tropical forest, Ecology, 91, 1730-1739, 2010.

Cosgrove , D. J.: How do plant cell walls extend? Plant Physiol., 102, 1-6, 1993.

Cox, P. M., Harris, P. P., Huntingford, C., Betts, R. A., Collins, M., Jones, C. D., Jupp, T. E., Marengo, J. A., and Nobre, C. A.: Increasing risk of Amazonian drought due to decreasing aerosol pollution, Nature, 453, 212-215, 2008.

Cullen, L. E., Adams, M. A., Anderson, M. J., and Grierson, P. F.: Analyses of $\delta^{13} \mathrm{C}$ and delta $\delta^{18} \mathrm{O}$ in tree rings of Callitris columellaris provide evidence of a change in stomatal control of photosynthesis in response to regional changes in climate, Tree Physiol., 28, 1525-1533, 2008.

Culmsee, H. and Pitopang, R.: Tree diversity in sub-montane and 
lower montane primary rain forests in Central Sulawesi, Blumea, 54, 119-123, 2009.

Culmsee, H., Leuschner, C., Moser, G., and Pitopang, R.: Forest aboveground biomass along an elevational transect in Sulawesi, Indonesia, and the role of Fagaceae in tropical montane rain forests, J. Biogeogr., 37, 960-974, 2010.

da Costa, A. C. L., Galbraith, D., Almeida, S., Portela, B. T. T., da Costa, M., Silva, J. D., Braga, A. P., de Goncalves, P. H. L., de Oliveira, A. A. R., Fisher, R., Phillips, O. L., Metcalfe, D. B., Levy, P., and Meir, P.: Effect of $7 \mathrm{yr}$ of experimental drought on vegetation dynamics and biomass storage of an eastern Amazonian rainforest, New Phytol., 187, 579-591, 2010.

Diaz, M. and Granadillo, E.: The significance of episodic rains for reproductive phenology and productivity of trees in semiarid regions of northwestern Venezuela, Trees-Struct. Funct., 19, 336348, 2005.

Dietz, J., Leuschner, C., Holscher, D., and Kreilein, H.: Vertical patterns and duration of surface wetness in an old-growth tropical montane forest, Indonesia, Flora, 202, 111-117, 2007.

Domec, J. C., Warren, J. M., Meinzer, F. C., and Lachenbruch, B.: Safety Factors for Xylem Failure by Implosion and Air-Seeding Within Roots, Trunks and Branches of Young and Old Conifer Trees, Iawa J., 30(2), 101-120, 2009.

Eilmann, B., Weber, P., Rigling, A., and Eckstein, D.: Growth reactions of Pinus sylvestris L. and Quercus pubescens Willd. to drought years at a xeric site in Valais, Switzerland, Dendrochronologia, 23, 121-132, 2006.

Erasmi, S., Propastin, P., Kappas, M., and Panferov, O.: Spatial Patterns of NDVI Variation over Indonesia and Their Relationship to ENSO Warm Events during the Period 1982-2006, J. Climate, 22, 6612-6623, 2009.

Fisher, R. A., Williams, M., Da Costa, A. L., Malhi, Y., Da Costa, R. F., Almeida, S., and Meir, P.: The response of an Eastern Amazonian rain forest to drought stress: results and modelling analyses from a throughfall exclusion experiment, Glob. Change Biol., 13, 2361-2378, 2007.

Floyd, M. L., Clifford, M., Cobb, N. S., Hanna, D., Delph, R., Ford, P., and Turner, D.: Relationship of stand characteristics to drought-induced mortality in three Southwestern pinon-juniper woodlands, Ecol. Appl., 19, 1223-1230, 2009.

Fotelli, M. N., Radoglou, K., Nahm, M., and Rennenberg, H.: Climate effects on the nitrogen balance of beech (Fagus sylvatica) at its south-eastern distribution limit in Europe, Plant Biosyst., 143, S34-S45, 2009.

Garcia-Gonzalez, I. and Eckstein, D.: Climatic signal of earlywood vessels of oak on a maritime site, Tree Physiol., 23, 497-504, 2003.

Gessler, A., Keitel, C., Nahm, M., and Rennenberg, H.: Water shortage affects the water and nitrogen balance in central European beech forests, Plant Biol., 6, 289-298, 2004.

Goff, J. A. and Gratch, S.: Low-pressure properties of water from -160 to $212{ }^{\circ} \mathrm{F}$, in: 52nd annual meeting of the American Society of Heating and Ventilating Engineers. Transactions of the American Society of Heating and Ventilating Engineers, New York, 95-122, 1946.

Gollan, T., Schurr, U., and Schulze, E. D.: Stomatal Response to Drying Soil in Relation to Changes in the Xylem Sap Composition of Helianthus-Annuus. 1. the Concentration of Cations, Anions, Amino-Acids In, and $\mathrm{Ph}$ Of, the Xylem Sap, Plant Cell
Environ., 15, 551-559, 1992.

Granier, A., Reichstein, M., Breda, N., Janssens, I. A., Falge, E., Ciais, P., Grunwald, T., Aubinet, M., Berbigier, P., Bernhofer, C., Buchmann, N., Facini, O., Grassi, G., Heinesch, B., Ilvesniemi, H., Keronen, P., Knohl, A., Kostner, B., Lagergren, F., Lindroth, A., Longdoz, B., Loustau, D., Mateus, J., Montagnani, L., Nys, C., Moors, E., Papale, D., Peiffer, M., Pilegaard, K., Pita, G., Pumpanen, J., Rambal, S., Rebmann, C., Rodrigues, A., Seufert, G., Tenhunen, J., Vesala, I., and Wang, Q.: Evidence for soil water control on carbon and water dynamics in European forests during the extremely dry year: 2003, Agr. Forest Meteorol., 143, 123-145, 2007.

Hacke, U. G., Plavcova, L., meida-Rodriguez, A., King-Jones, S., Zhou, W. C., and Cooke, J. E. K.: Influence of nitrogen fertilization on xylem traits and aquaporin expression in stems of hybrid poplar, Tree Physiol., 30, 1016-1025, 2010.

Hanson, P. J. and O'Hara, F. M.: The need for Large-Scale ClimateChange Studies, in: North American Temperate Deciduous Forest Responses to Changing Precipitation Regimes, edited by: Hanson, P. J. and Wullschleger, S. D., Ecological Studies 166, Springer, New York, 3-7, 2003.

Herbette, S. and Cochard, H.: Calcium Is a Major Determinant of Xylem Vulnerability to Cavitation, Plant Physiol., 153, 19321939, 2010.

Hertel, D., Leuschner, C., and Holscher, D.: Size and structure of fine root systems in old-growth and secondary tropical montane forests (Costa Rica), Biotropica, 35, 143-153, 2003.

Hertel, D., Moser, G., Culmsee, H., Erasmi, S., Horna, V., Schuldt, B., and Leuschner, C.: Below- and above-ground biomass and net primary production in a paleotropical natural forest $(\mathrm{Su}-$ lawesi, Indonesia) as compared to neotropical forests, Forest Ecol. Manag., 258, 1904-1912, 2009.

Holbrook, N. M.: Stem water storage, in: Plant Stems: Physiology and Functional Morphology, edited by: Gartner, B. L., Academic Press, San Diego, 151-174, 1995.

Horna, V., Schuldt, B., Brix, S., and Leuschner, C.: Environment and tree size controlling stem sap flux in a perhumid tropical forest of Central Sulawesi, Indonesia, Ann. For. Sci., doi:10.1007/s13595-011-0110-2, in press, 2011.

Hulme, M. and Viner, D.: A climate change scenario for the tropics, Climatic Change, 39, 145-176, 1998.

Ichie, T., Hiromi, T., Yoneda, R., Kamiya, K., Kohira, M., Ninomiya, I., and Ogino, K.: Short-term drought causes synchronous leaf shedding and flushing in a lowland mixed dipterocarp forest, Sarawak, Malaysia, J. Trop. Ecol., 20, 697-700, 2004.

James, S. A., Meinzer, F. C., Goldstein, G., Woodruff, D., Jones, T., Restom, T., Mejia, M., Clearwater, M., and Campanello, P.: Axial and radial water transport and internal water storage in tropical forest canopy trees, Oecologia, 134, 37-45, 2003.

Jiménez, E. M., Moreno, F. H., Peñuela, M. C., Patiño, S., and Lloyd, J.: Fine root dynamics for forests on contrasting soils in the Colombian Amazon, Biogeosciences, 6, 2809-2827, doi:10.5194/bg-6-2809-2009, 2009.

Kitin, P., Voelker, S. L., Meinzer, F. C., Beeckman, H., Strauss, S. H., and Lachenbruch, B.: Tyloses and Phenolic Deposits in Xylem Vessels Impede Water Transport in Low-Lignin Transgenic Poplars: A Study by Cryo-Fluorescence Microscopy, Plant Physiol., 154, 887-898, 2010. 
Koch, G. W., Sillett, S. C., Jennings, G. M., and Davis, S. D.: The limits to tree height, Nature, 428, 851-854, 2004.

Kreuzwieser, J. and Gessler, A.: Global climate change and tree nutrition: influence of water availability, Tree Physiol., 30, 1221-1234, 2010.

Markewitz, D., Devine, S., Davidson, E. A., Brando, P., and Nepstad, D. C.: Soil moisture depletion under simulated drought in the Amazon: impacts on deep root uptake, New Phytol., 187, 592-607, 2010.

McDonald, A. J. S. and Davies, W. J.: Keeping in touch: Responses of the whole plant to deficits in water and nitrogen supply, Adv. Bot. Res., 22, 229-300, 1996.

McDowell, N., Barnard, H., Bond, B. J., Hinckley, T., Hubbard, R. M., Ihsii, H., Köstner, B., Magnani, F., Marshall, J. D., Meinzer, F. C., Phillips, N., Ryan, M. G., and Whitehead, D.: The relationship between tree height and leaf area: sapwood area ratio, Oecologia, 132, 12-20, 2002.

McElrone, A. J., Grant, J. A., and Kluepfel, D. A.: The role of tyloses in crown hydraulic failure of mature walnut trees afflicted by apoplexy disorder, Tree Physiol., 30, 761-772, 2010.

Meir, P. and Woodward, F. I.: Amazonian rain forests and drought: response and vulnerability, New Phytol., 187, 553-557, 2010.

Mullin, L. P., Sillett, S. C., Koch, G. W., Tu, K. P., and Antoine, M. E.: Physiological consequences of height-related morphological variation in Sequoia sempervirens foliage, Tree Physiol., 29, 999-1010, 2009.

Nepstad, D. C., Moutinho, P., Dias, M. B., Davidson, E., Cardinot, G., Markewitz, D., Figueiredo, R., Vianna, N., Chambers, J., Ray, D., Guerreiros, J. B., Lefebvre, P., Sternberg, L., Moreira, M., Barros, L., Ishida, F. Y., Tohlver, I., Belk, E., Kalif, K., and Schwalbe, K.: The effects of partial throughfall exclusion on canopy processes, aboveground production, and biogeochemistry of an Amazon forest, J. Geophys. Res.-Atmos., 107(D20), 8085, doi:10.1029/2001JD000360, 2002.

Nepstad, D. C., Tohver, I. M., Ray, D., Moutinho, P., and Cardinot, G.: Mortality of large trees and lianas following experimental drought in an amazon forest, Ecology, 88, 2259-2269, 2007.

Newbery, D. M. and Lingenfelder, M.: Plurality of tree species responses to drought perturbation in Bornean tropical rain forest, Plant Ecol., 201, 147-167, 2009.

Oldham, A. R., Sillett, S. C., Tomescu, A. M. F., and Koch, G. W.: The Hydrostatic Gradient, Not Light Availability, Drives HeightRelated Variation in Sequoia Sempervirens (Cupressaceae) Leaf Anatomy, Am. J. Bot., 97, 1087-1097, 2010.

Oliveira, R. S., Dawson, T. E., and Burgess, S. S. O.: Evidence for direct water absorption by the shoot of the desiccation-tolerant plant Vellozia flavicans in the savannas of central Brazil, J. Trop. Ecol., 21, 585-588, 2005.

Phillips, N. G., Ryan, M. G., Bond, B. J., McDowell, N. G., Hinckley, T. M., and Cermak, J.: Reliance on stored water increases with tree size in three species in the Pacific Northwest, Tree Physiol., 23, 237-245, 2003.

Phillips, O. L., Aragao, L. E. O. C., Lewis, S. L., Fisher, J. B., Lloyd, J., Lopez-Gonzalez, G., Malhi, Y., Monteagudo, A., Peacock, J., Quesada, C. A., van der Heijden, G., Almeida, S., Amaral, I., Arroyo, L., Aymard, G., Baker, T. R., Banki, O., Blanc, L., Bonal, D., Brando, P., Chave, J., de Oliveira, A. C. A., Cardozo, N. D., Czimczik, C. I., Feldpausch, T. R., Freitas, M. A., Gloor, E., Higuchi, N., Jimenez, E., Lloyd, G., Meir, P., Mendoza, C.,
Morel, A., Neill, D. A., Nepstad, D., Patino, S., Penuela, M. C., Prieto, A., Ramirez, F., Schwarz, M., Silva, J., Silveira, M., Thomas, A. S., ter Steege, H., Stropp, J., Vasquez, R., Zelazowski, P., Davila, E. A., Andelman, S., Andrade, A., Chao, K. J., Erwin, T., Di Fiore, A., Honorio, E., Keeling, H., Killeen, T. J., Laurance, W. F., Cruz, A. P., Pitman, N. C. A., Vargas, P. N., Ramirez-Angulo, H., Rudas, A., Salamao, R., Silva, N., Terborgh, J., and Torres-Lezama, A.: Drought Sensitivity of the Amazon Rainforest, Science, 323, 1344-1347, 2009.

Phillips, O. L., van der Heijden, G., Lewis, S. L., Lopez-Gonzalez, G., Aragao, L. E. O. C., Lloyd, J., Malhi, Y., Monteagudo, A., Almeida, S., Davila, E. A., Amaral, I., Andelman, S., Andrade, A., Arroyo, L., Aymard, G., Baker, T. R., Blanc, L., Bonal, D., de Oliveira, A. C. A., Chao, K. J., Cardozo, N. D., da Costa, L., Feldpausch, T. R., Fisher, J. B., Fyllas, N. M., Freitas, M. A., Galbraith, D., Gloor, E., Higuchi, N., Honorio, E., Jimenez, E., Keeling, H., Killeen, T. J., Lovett, J. C., Meir, P., Mendoza, C., Morel, A., Vargas, P. N., Patino, S., Peh, K. S. H., Cruz, A. P., Prieto, A., Quesada, C. A., Ramirez, F., Ramirez, H., Rudas, A., Salamao, R., Schwarz, M., Silva, J., Silveira, M., Slik, J. W. F., Sonke, B., Thomas, A. S., Stropp, J., Taplin, J. R. D., Vasquez, R., and Vilanova, E.: Drought-mortality relationships for tropical forests, New Phytol., 187, 631-646, 2010.

Poyatos, R., Cermak, J., and Llorens, P.: Variation in the radial patterns of sap flux density in pubescent oak (Quercus pubescens) and its implications for tree and stand transpiration measurements, Tree Physiol., 27, 537-548, 2007.

R Development Core Team: R: a language and environment for statistical computing, R Foundation for Statistical Computing, Vienna, Austria, version 2.12.1, http://www.R-project.org, 2009.

Rennenberg, H., Dannenmann, M., Gessler, A., Kreuzwieser, J., Simon, J., and Papen, H.: Nitrogen balance in forest soils: nutritional limitation of plants under climate change stresses, Plant Biol., 11, 4-23, 2009.

Ryan, M. G. and Yoder, B. J.: Hydraulic limits to tree height and tree growth, Bioscience, 47, 235-242, 1997.

Sass, U. and Eckstein, D.: The Variability of Vessel Size in Beech (Fagus-Sylvatica L.) and Its Ecophysiological Interpretation, Trees-Struct. Funct., 9, 247-252, 1995.

Scheidegger, Y., Saurer, M., Bahn, M., and Siegwolf, R.: Linking stable oxygen and carbon isotopes with stomatal conductance and photosynthetic capacity: a conceptual model, Oecologia, 125, 350-357, 2000.

Schenk, H. J. and Jackson, R. B.: The global biogeography of roots, Ecol. Monogr., 72, 311-328, 2002.

Sheffield, J. and Wood, E. F.: Projected changes in drought occurrence under future global warming from multi-model, multiscenario, IPCC AR4 simulations, Clim. Dynam., 31, 79-105, 2008.

Sillett, S. C., Van Pelt, R., Koch, G. W., Ambrose, A. R., Carroll, A. L., Antoine, M. E., and Mifsud, B. M.: Increasing wood production through old age in tall trees, Forest Ecol. Manag., 259, 976-994, 2010.

Slik, J. W. F.: El Nino droughts and their effects on tree species composition and diversity in tropical rain forests, Oecologia, 141, 114-120, 2004.

Sperry, J. S., Donnelly, J. R., and Tyree, M. T.: A Method for Measuring Hydraulic Conductivity and Embolism in Xylem, Plant Cell Environ., 11, 35-40, 1988. 
Sperry, J. S., Nichols, K. L., Sullivan, J. E. M., and Eastlack, S. E.: Xylem Embolism in Ring-Porous, Diffuse-Porous, and Coniferous Trees of Northern Utah and Interior Alaska, Ecology, 75, 1736-1752, 1994.

Timmermann, A., Oberhuber, J., Bacher, A., Esch, M., Latif, M., and Roeckner, E.: Increased El Nino frequency in a climate model forced by future greenhouse warming, Nature, 398, 694697, 1999.

Tyree, M. T.: Hydraulic limits on tree performance: transpiration, carbon gain and growth of trees, Trees-Struct. Funct., 17, 95100, 2003.

Tyree, M. T., Cochard, H., Cruiziat, P., Sinclair, B., and Ameglio, T.: Drought-induced leaf shedding in walnut - evidence for vulnerability segmentation, Plant Cell Environ., 16, 879-882, 1993.

Van Genuchten, M. T.: A Closed-Form Equation for Predicting the Hydraulic Conductivity of Unsaturated Soils, Soil Sci. Soc. Am. J., 44, 892-898, 1980.

Van Nieuwstadt, M. G. L. and Sheil, D.: Drought, fire and tree survival in a Borneo rain forest, East Kalimantan, Indonesia, J. Ecol., 93, 191-201, 2005.

Veldkamp, E. and O'Brien, J. J.: Calibration of a frequency domain reflectometry sensor for humid tropical soils of volcanic origin, Soil Sci. Soc. Am. J., 64, 1549-1553, 2000.
White, F. M.: Viscous fluid flow, McGraw-Hill, New York, 736 pp., 1991.

Williams, J. W., Jackson, S. T., and Kutzbacht, J. E.: Projected distributions of novel and disappearing climates by $2100 \mathrm{AD}, \mathrm{P}$. Natl. Acad. Sci. USA, 104, 5738-5742, 2007.

Yates, D. J. and Hutley, L. B.: Foliar Uptake of Water by Wet Leaves of Sloanea-Woollsii, An Australian Subtropical RainForest Tree, Aust. J. Bot., 43, 157-167, 1995.

Zach, A., Schuldt, B., Brix, S., Horna, V., Culmsee, H., and Leuschner, C.: Vessel diameter and xylem hydraulic conductivity increase with tree height in tropical rainforest trees in Sulawesi, Indonesia, Flora, 205, 506-512, 2010.

Zhu, S. D. and Cao, K. F.: Hydraulic properties and photosynthetic rates in co-occurring lianas and trees in a seasonal tropical rainforest in southwestern China, Plant Ecol., 204, 295-304, 2009.

Zwieniecki, M. A., Melcher, P. J., and Holbrook, N. M.: Hydraulic properties of individual xylem vessels of Fraxinus americana, J. Exp. Bot., 52, 257-264, 2001. 